DOI: $10.5800 / G T-2020-11-4-0500$

\title{
KIMBERLITE-LIKE ROCKS OF THE URIK-IYA GRABEN, EASTERN SAYAN REGION: MINERAL COMPOSITION, GEOCHEMISTRY AND FORMATION CONDITIONS
}

\author{
V.B. Savel'eva ${ }^{\otimes}$, Yu.V. Danilova $\odot$, E.P. Bazarova $\odot$, B.S. Danilov $₫$
}

Institute of the Earth's Crust, Siberian Branch of the Russian Academy of Science, 128 Lermontov St, Irkutsk 664033, Russia

ABSTRACT. The study of the Bol'shaya Tagna alkaline-carbonatite massif and adjacent areas was focused on the mineral and chemical compositions of minerals, the distribution of petrogenic and trace elements in pyroxene-free alkaline picrites in veins and dikes dated at the late Riphean (circa $645 \mathrm{Ma}$ ), and comparison with the Bushkanai kimberlite-picrite dike. Phenocrysts in the pyroxene-free picrites are represented by olivine (replaced with serpentine) and phlogopite; the bulk is formed by serpentine, phlogopite, monticellite, calcite, etc .; xenocrysts of pyrope and chrome diopside are absent. Phlogopite and $\mathrm{Cr}$-spinel from the picrites are chemically similar to these minerals in kimberlites, but the evolution of the spinel compositions corresponds to the titanomagnetite trend; monticellite is depleted in forsterite $\left(\mathrm{Mg}_{2} \mathrm{SiO}_{4}\right)$. The rocks contain strontianite, burbankite, titanium andradite, calcirtite and $\mathrm{Mn}$-ilmenite, which are not typical of kimberlites, but are inherent in carbonate-bearing ultramafic lamprophyres, ayllikites. The pyroxene-free picrites have low contents (wt \%) of $\mathrm{SiO}_{2}$ (28.4-33.2), $\mathrm{Al}_{2} \mathrm{O}_{3}(3.2-5.6)$, and $\mathrm{Na}_{2} \mathrm{O}(0.01-0.05)$; relatively high contents of $\mathrm{TiO}_{2}(2.0-3.3)$, and $\mathrm{K}_{2} \mathrm{O}$ (0.45-1.33); varying contents of $\mathrm{MgO}$ (16.1-24.1), $\mathrm{CaO}$ (12.9-22.8), $\mathrm{CO}_{2}$ (1.1-12.2), $\mathrm{Ni}(260-850 \mathrm{ppm})$, and $\mathrm{Cr}(840-2200$ $\mathrm{ppm}$ ); and $\mathrm{Mg \#}=0.73-0.80$. The contents of $\mathrm{Th}, \mathrm{U}, \mathrm{Nb}, \mathrm{Ta}, \mathrm{La}$, and $\mathrm{Ce}$ in the veins are approximately two orders higher than those in the primitive mantle; the spectra of trace elements differ from the spectra of the South African and Yakuian kimberlites. In the pyroxene-free picrites and the rocks of the Bushkanai dike, the $\mathrm{Nb} / \mathrm{U}, \mathrm{Nb} / \mathrm{Th}, \mathrm{Th} / \mathrm{Ce}, \mathrm{La} / \mathrm{Nb}$, and $\mathrm{Zr} / \mathrm{Nb}$ ratios are similar to those in ocean island basalts (OIB) and thus give evidence of the leading contribution of the recycled component into the source melt. In experiments conducted to investigate melting of carbonated garnet lherzolite, the pyroxene-free alkaline picrites melted at 5-6 GPa.

KEYWORDS: kimberlite; pyroxene-free alkaline picrite; phlogopite; spinel; monticellite; Urik-Iya graben; Zima complex; Bol'shaya Tagna massif; Sayan region

FUNDING: The study was financially supported by the Russian Science Foundation (RSF-18-17-00101) and the Irkutsk Scientific Center SB RAS (Block 1.4 of the Integration Project).

\section{RESEARCH ARTICLE}

Correspondence: Valentina B. Savel'eva, vsavel@crust.irk.ru
Received: August 27, 2020

Revised: October 5, 2020

Accepted: October 10, 2020

FOR CITATION: Savel'eva V.B., Danilova Yu.V., Bazarova E.P., Danilov B.S., 2020. Kimberlite-like rocks of the Urik-Iya graben, Eastern Sayan region: mineral composition, geochemistry and formation conditions. Geodynamics \& Tectonophysics 11 (4), 678-696. doi: 10.5800/GT-2020-11-4-0500

Supplementary files: Savel'eva et al_suppl.xlsx 


\title{
КИМБЕРЛИТОПОДОБНЫЕ ПОРОДЫ УРИКСКО-ИЙСКОГО ГРАБЕНА, ВОСТОЧНОЕ ПРИСАЯНЬЕ: МИНЕРАЛЬНЫЙ СОСТАВ, ГЕОХИМИЯ И УСЛОВИЯ ФОРМИРОВАНИЯ
}

\author{
В.Б. Савельева, Ю.В. Данилова, Е.П. Базарова, Б.С. Данилов
}

Институт земной коры СО РАН, 664033, Иркутск, ул. Лермонтова, 128, Россия

АНноТАЦИЯ. Изучен химический состав минералов, распределение петрогенных и редких элементов в беспироксеновых щелочных пикритах, образующих жилы и дайки в позднерифейском (около 645 млн лет) Большетагнинском щелочно-карбонатитовом массиве и за его пределами, выполнено их сопоставление с Бушканайской дайкой кимберлит-пикритового состава. Вкрапленники в беспироксеновых пикритах представлены оливином (замещен серпентином) и флогопитом, основная масса образована серпентином, флогопитом, монтичеллитом, кальцитом и др.; ксенокристы пиропа, хромдиопсида отсутствуют. Флогопит и $\mathrm{Cr}$-шпинель из пикритов по химическому составу сходны с этими минералами в кимберлитах, но эволюция состава шпинелидов отвечает титаномагнетитовому тренду; монтичеллит обеднен форстеритовым $\left(\mathrm{Mg}_{2} \mathrm{SiO}_{4}\right)$ компонентом. Породы содержат стронцианит, бурбанкит, титанистый андрадит, кальциртит, Мn-ильменит, не характерные для кимберлитов, но присущие карбонатсодержащим ультрамафическим лампрофирам - айлликитам. Беспироксеновые пикриты имеют низкое содержание (мас. \%) $\mathrm{SiO}_{2}(28.4-33.2), \mathrm{Al}_{2} \mathrm{O}_{3}(3.2-5.6), \mathrm{Na}_{2} \mathrm{O}(0.01-0.05)$, умеренно высокое $\mathrm{TiO}_{2}(2.0-3.3)$, $\mathrm{K}_{2} \mathrm{O}$ (0.45-1.33), варьирующееся $\mathrm{MgO}$ (16.1-24.1), СaO (12.9-22.8), $\mathrm{CO}_{2}(1.1-12.2)$, а также $\mathrm{Ni}(260-850 \mathrm{ppm})$, Cr (840-2200 ppm); Mg\#=0.73-0.80. Содержание Th, U, Nb, Ta, La, Се в жилах повышено примерно на два порядка по сравнению с примитивной мантией; спектры микроэлементов отличаются от спектров южно-африканских и якутских кимберлитов. Отношения $\mathrm{Nb} / \mathrm{U}, \mathrm{Nb} / \mathrm{Th}, \mathrm{Th} / \mathrm{Ce}, \mathrm{La} / \mathrm{Nb}, \mathrm{Zr} / \mathrm{Nb}$ в беспироксеновых пикритах и в породах Бушканайской дайки близки к таковым в OIB, что отражает ведущий вклад рециклированного компонента в источник расплавов. На основе результатов экспериментов по плавлению карбонатизированного гранатового лерцолита показано, что выплавление беспироксеновых щелочных пикритов происходило при 5-6 GРа.

КЛЮЧЕВЫЕ СЛОВА: кимберлит; беспироксеновый щелочной пикрит; флогопит; шпинель; монтичеллит; Урикско-Ийский грабен; зиминский комплекс; Большетагнинский массив; Присаянье

ФИНАНСИРОВАНИЕ: Работа выполнена при финансовой поддержке РНФ (РНФ-18-17-00101) и ИНЦ СО РАН (Интеграционный проект, блок 1.4).

\section{1. ВВЕДЕНИЕ}

Территория Восточного Присаянья на юго-западе Сибирской платформы является одним из регионов, перспективных для обнаружения россыпных и коренных месторождений алмазов [Egorov et al., 2010; Odintsov et al., 1962; Pokhilenko et al., 2012]. Здесь выделяются три основных этапа калиевого ультраосновного щелочного магматизма: мезопротерозойский $(\sim 1200$ млн лет), неопротерозойский ( 620-650 млн лет) и среднепалеозойский ( 370 млн лет) [Egorov et al., 2010; Sekerin et al., 1995; Ashchepkov et al., 2020; Doroshkevich et al., 2016]. Неопротерозойский этап характеризуется наиболее интенсивным проявлением калиевого мантийного магматизма: в это время на территории Урикско-Ийского грабена формировались крупные массивы щелочных пород и карбонатитов зиминского комплекса, дайки и жилы ультраосновных фоидитов, щелочных и субщелочных пикритов, ультрамафических лампрофиров и более редкие тела кимберлитов. К последним относят Бушканайскую дайку кимберлит-пикритового состава [Egorov et al., 2010; Minaeva, Egorov, 2008] (рис. 1) и одну из жил Ингашинского поля [Kostrovitsky et al., 2007] (юго-восточнее рассматриваемой территории).

В пределах Большетагнинского и Белозиминского массивов и во вмещающей песчано-сланцевой толще распространены жилы и дайки пикритовых порфиритов (беспироксеновых щелочных пикритов [Petrographic Code ..., 2008]), сходных по внешнему облику и петрографическому составу с кимберлитами [Pozharitskaya, Samoilov, 1972; Frolov, Belov, 1999; Chernyshova, 1991]). Целью работы является минералого-геохимическая типизация кимберлитоподобных жил Большетагнинского массива в сопоставлении с Бушканайской кимберлит-пикритовой дайкой.

\section{2. ГЕОЛОГИЧЕСКОЕ СТРОЕНИЕ РАЙОНА}

Урикско-Ийский грабен находится на юго-западной окраине Сибирской платформы и представляет собой линейную зону северо-западного простирания шириной до 30 км, протяженностью до 200 км между краевыми выступами фундамента кратона (рис. 1, а). С югозапада грабен ограничен зоной Главного Саянского разлома, а его северная часть перекрывается позднедокембрийскими толщами Присаянского прогиба. Согласно [Gladkochub et al., 2014], грабен представляет собой палеоавлакоген, сформировавшийся в несколько этапов во временном интервале примерно от 1.911.87 млрд лет и до 1.53 млрд лет. Грабен сложен вулканогенно-осадочными отложениями раннего протерозоя и раннего рифея, неравномерно дислоцированными 
и метаморфизованными преимущественно до уровня зеленосланцевой фации. Отложения палеопротерозоя прорываются дайками базитов (1.91 млрд лет) и гранитами саянского комплекса (1.87-1.83 млрд лет), а отложения мезопротерозоя - гранитоидами чернозиминского комплекса (1.53 млрд лет); после рубежа 1.5 млрд лет Урикско-Ийский грабен превратился во внутри- кратонную область стабильного развития [Gladkochub et al., 2014].

Формирование зиминского комплекса связано с крупной структурной перестройкой в конце позднего рифея, когда произошел раскол суперконтинента Родиния, включавшего в виде составной части Сибирский кратон [Yarmolyuk, Kovalenko, 2003]. Комплекс

(б)

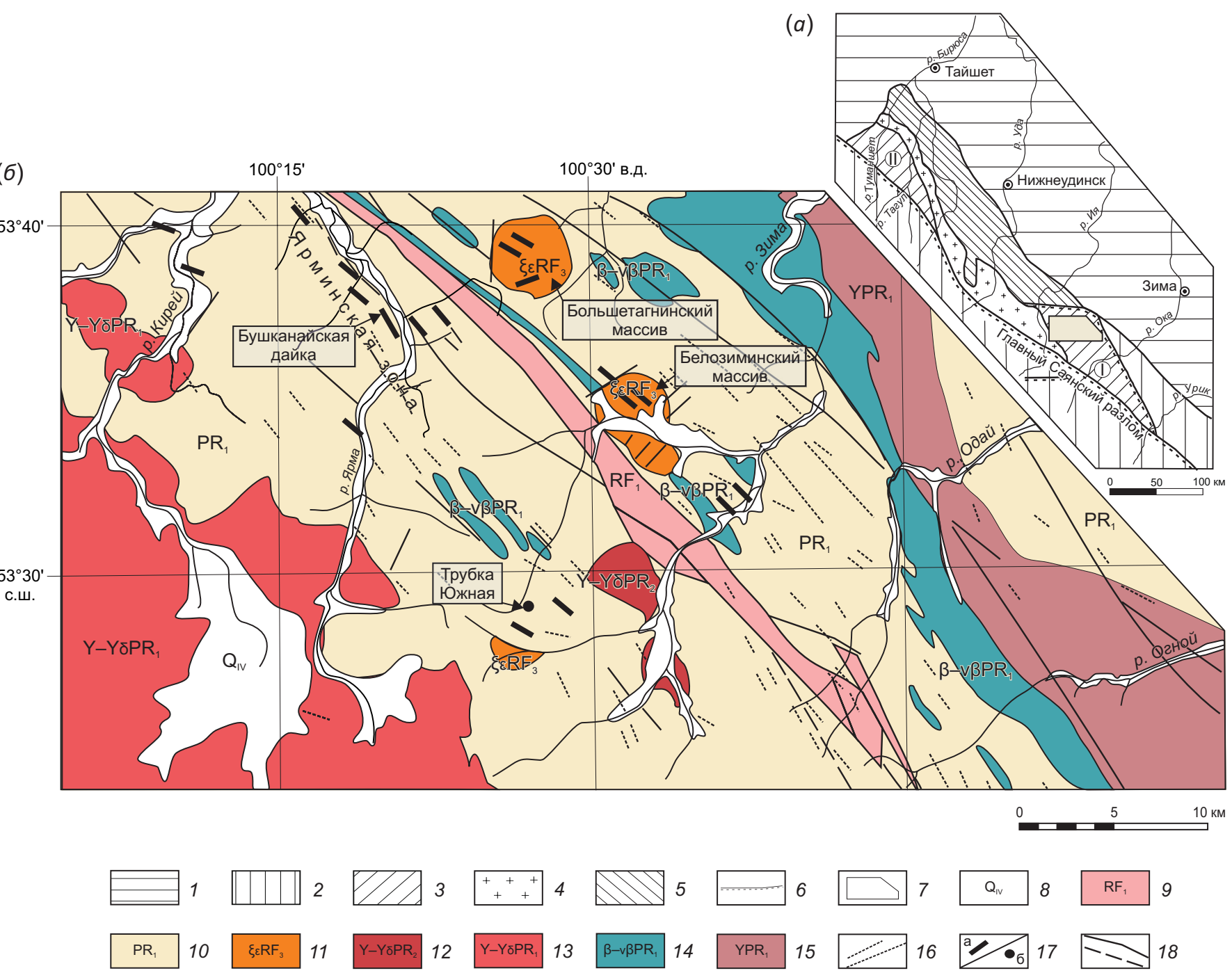

Рис. 1. Схемы расположения зиминского комплекса в структурах юго-западной окраины Сибирской платформы (a) и геологического строения участка работ (б).

(a): 1 - фанерозойский осадочный чехол; 2 - раннедокембрийские гранитогнейсовые комплексы; 3 - грабены PR : I - УрикскоИйский, II - Туманшетский; 4 - граниты $\mathrm{PR}_{1} ; 5$ - отложения Присаянского прогиба (верхний рифей - венд); 6 - крупнейшие разломы; 7 - участок работ. (б): 8 - кайнозойские отложения; 9 - терригенные отложения $\mathrm{RF}_{1} ; 10$ - вулканогенно-осадочные отложения $\mathrm{PR}_{1} ; 11$ - зиминский комплекс ультраосновных щелочных пород и карбонатитов $\mathrm{RF}_{3} ; 12$ - гранитоиды чернозиминского комплекса $\mathrm{PR}_{2} ; 13$ - граниты саянского комплекса $\mathrm{PR}_{1} ; 14$ - габбро-диабазы $\mathrm{PR}_{1} ; 15$ - гнейсограниты $\mathrm{PR}_{1} ; 16$ жилы основного состава нерасчлененные; 17 - дайки, жилы (а) и трубки (б) ультраосновного щелочного состава (вне масштаба); 18 - разломы.

Fig. 1. Schematic maps showing the locations of the Zima complex in the structures of the southwestern margin of the Siberian platform (a), and the geological structure of the study area (б).

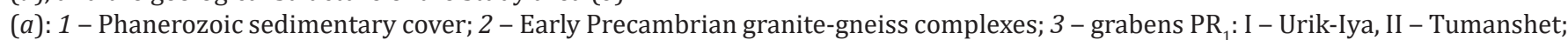
4 - granite $\mathrm{PR}_{1} ; 5$ - deposits of the Sayan trough (Upper Riphean - Vendian); 6 - largest faults; 7 - study area. (б): 8 - Cenozoic deposits; 9 - terrigenous deposits $\mathrm{RF}_{1} ; 10$ - volcanic-sedimentary deposits $\mathrm{PR}_{1} ; 11$ - Zima complex of ultrabasic-alkaline rocks and carbonatite $\mathrm{RF}_{3} ; 12$ - granitoid of the Chernoziminsky complex $\mathrm{PR}_{2} ; 13$ - granite of the Sayan complex $\mathrm{PR}_{1} ; 14$ - gabbro diabase $\mathrm{PR}_{1}$; 15 - gneiss-granite $\mathrm{PR}_{1} ; 16$ - non-segmented veins of the main composition; 17 - dikes, veins (a) and pipes (б) of the ultrabasic alkaline composition (out of scale); 18 - faults. 
представлен [Frolov, Belov, 1999] ийолитами, мельтейгитами, уртитами, нефелиновыми сиенитами, сиенитами, карбонатитами, слагающими Белозиминский, Большетагнинский и Среднезиминский массивы, а также щелочными пикритами и альнёитами (рис. 1, б). Размещение щелочно-карбонатитовых тел контролируется зонами разломов северо-западного простирания. Возраст нефелиновых сиенитов Белозиминского массива по результатам датирования циркона $\mathrm{U}-\mathrm{Pb}$ методом составляет 643 4 млн лет [Yarmolyuk et al., 2005]; такой же возраст - 645 6 млн лет - получен U-Pb методом по Ca-Ti-Fe гранату из ийолита [Salnikova et al., 2019] и ${ }^{40} \mathrm{Ar}-{ }^{39} \mathrm{Ar}$ методом по флогопиту из наиболее поздних анкеритовых карбонатитов [Doroshkevich et al., 2016], что указывает на формирование щелочных силикатных пород и карбонатитов в узком временном интервале.

Большетагнинский массив имеет зонально-кольцевое строение (рис. 2) и сложен ийолитами-мельтейгитами, нефелиновыми и щелочными сиенитами, калишпатовыми сиенитами, карбонатитами (кальцитовыми ранней стадии и анкеритовыми поздней) [Frolov, Belov, 1999]. Жилы и дайки ультраосновных пород имеют крутопадающее залегание, мощность от первых десятков сантиметров до 10-20 м и протяженность до нескольких сотен метров. Дайки и жилы пикритовых порфиритов (беспироксеновых щелочных пикритов, или кимберлитоидов [Petrographic Code ..., 2008]) прорывают ийолиты и сиениты, а по взаимоотношениям с карбонатитами выделяются интра- и послекарбонатитовые тела [Frolov, Belov, 1999]. Авторами статьи также наблюдалась жила беспироксенового пикрита среди кальцитового карбонатита, которая прорывалась карбонатным прожилком, что указывает на интракарбонатитовый возраст жилы.

Ярминская зона находится на расстоянии 6-10 км от Белозиминского и Большетагнинского массивов и приурочена к разломам северо-западного простирания (см. рис. 1, б). Зона характеризуется локализацией в ней жильных, жильно-штокверковых и брекчиевых тел с Th-REE минерализацией, жил анкеритовых карбонатитов и щелочно-ультраосновных даек [Frolov et al.,

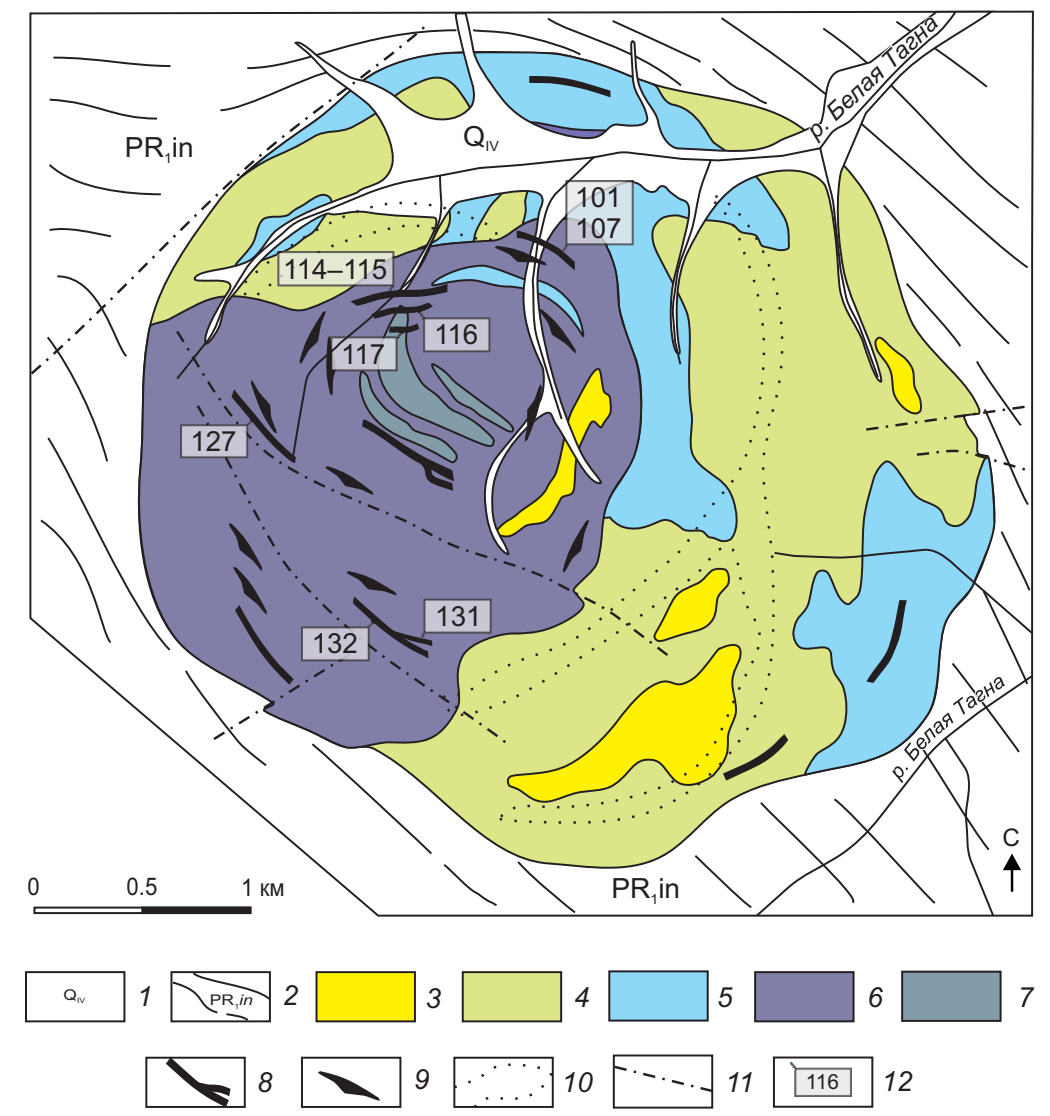

Рис. 2. Схема геологического строения Большетагнинского массива [Frolov, Belov, 1999].

1 - кайнозойские отложения; 2 - ингашинская свита PR: сланцы, песчаники, кварциты, доломиты; 3 - нефелиновые сиениты; 4 - калишпатовые сиениты; 5 - ийолиты; 6 - кальцитовые карбонатиты; 7 - кальцитовые карбонатиты с флюоритом и гематитом; 8 - дайки пикритов (вне масштаба); 9 - гематитовые рудные тела; 10 - апатит-пирохлоровые рудные зоны; 11 разломы; 12 - точки отбора проб.

Fig. 2. Schematic geological structure of the Bol'shaya Tagna massif [Frolov, Belov, 1999].

1 - Cenozoic deposits; 2 - Ingashi suite $\mathrm{PR}_{1}$ : shale, sandstone, quartzite, dolomite; 3 - nepheline syenite; 4 - potassium feldspar syenite; 5 - ijolite; 6 - calcite carbonatite; 7 - calcite carbonatite with fluorite and hematite; 8 - picrite dikes (out of scale); 9 - hematite ore bodies; 10 - apatite-pyrochlore ore zones; 11 - faults; 12 - sampling points. 
2005]. Бушканайская дайка мощностью около 2 м находится в правом борту р. Ярма, где прорывает песчано-сланцевые отложения нижнего протерозоя.

\section{3. ПЕТРОГРАФИЯ}

Бушканайская дайка представляет собой сложное тело, в котором выделяются три разновидности пород, отвечающие трем фазам внедрения. Продуктом наиболее ранней фазы является меланократовая неравномерно-зернистая порода, на 65-70 \% сложенная разновеликими (от 1-2 мм до 1.5 см) зернами серпентинизированного оливина (рис. 3 , а). Преобладают субидиоморфные зерна, наиболее крупные имеют корродированные границы. Встречаются также зерна хромдиопсида величиной до 2 см и каймы хромдиопсида на контакте серпентина и кальцита. Основная масса сложена хлоритизированным флогопитом, кальцитом, серпентином, серпентинизированным оливином II генерации, шпинелидами, апатитом, гидрогранатом. Согласно [Egorov et al., 2010; Minaeva, Egorov, 2008], эта порода является кимберлитом, и мы в статье придерживаемся этого названия (табл. 1).

Кимберлит присутствует в виде включений величиной до 20 см с отчетливыми границами в мезократовой породе с порфировидной структурой, слагающей в настоящее время обнажение. Вкрапленники величиной 2-7 мм образованы оливином (20-25 \%) и флогопитом (3-5 \%). Зерна оливина овальной формы, некоторые резорбированы. Оливин замещен серпентином с тонкой сыпью магнетита и кальцитом. Основная масса сложена гидрогранатом, шестоватыми зернами клинопироксена, замещенными гидрогранатом и тремолитом, а также флогопитом, шпинелидами, серпентинизированным оливином. Минеральный состав позволяет рассматривать эту породу как флогопит-пироксеновый пикрит [Petrographic Code ..., 2008].

В этой породе наблюдаются прожилки мощностью 5-10 см с неотчетливыми границами и неявнофлюидальной текстурой, богатые клинопироксеном (20-25\%) и слюдой (10-15\%), но бедные оливином (около $5 \%$ ) (рис. 3, б). Зерна клинопироксена величиной до 1 см имеют сглаженно-округлую, реже угловатую форму, оливин замещен серпентином, вкрапленники слюды достигают 2 см. Основная масса сложена флогопитом, хлоритом, апатитом, серпентином, кальцитом, диопсидом, шпинелидами, более поздними гранатом, тремолитом. По петрографическому составу эта порода также соответствует флогопит-пироксеновому пикриту (табл. 1), более богатому слюдой и клинопироксеном по сравнению с предыдущей разновидностью.

Беспироксеновые пикриты Большетагнинского массива представлены породами массивного облика, порфировидной структуры, темно-серого цвета. Вкрапленники величиной до 10-12 мм образованы зернами нацело серпентинизированного оливина (рис. 3, в). Крупные вкрапленники овальные с заливообразными границами, мелкие зерна субидиоморфные. В обр. 131 (рис. 3, д) в количестве 25-30 \% присутствуют вкрапленники флогопита величиной до 2-3 мм, частично или полностью замещенные хлоритом, но преимущественно слюда находится в основной массе. Нередко слюда замещена хлоритом, в отдельных жилах наблюдаются полные псевдоморфозы хлорита по флогопиту. В основной массе присутствуют также серпентин (15-20\%), кальцит (3-20\%), хлорит, тальк, титанистый гранат, шпинелиды (до 10 \%), апатит, перовскит, гидрогранат (10-35 \%), реже везувиан. В обр. 132 в основной массе среди гидрограната наблюдались реликты монтичеллита (ок. 5 \%) (рис. 3, г).

\section{4. СОСТАВ МИНЕРАЛОВ}

Анализы минералов (см. вкладку Дополнительные материалы на странице статьи) выполнены в Геологическом институте СО РАН (г. Улан-Удэ) на электронном сканирующем микроскопе «LEO-1430VP» (Carl Zeiss International) с энергодисперсионным анализатором «INCAEnergy 350» (Oxford Instruments Analytical Ltd.); аналитики Е.А. Хромова и Е. В. Ходырева.

Оливин - главный породообразующий минерал изученных пород в неизмененном виде или в реликтах не обнаружен ни в одном из тел.

Монтичеллит из беспироксенового пикрита Большетагнинского массива имеет однородный химический состав: отношение $\mathrm{Ca} /(\mathrm{Ca}+\mathrm{Mg})$ составляет $0.53-$ $0.54, \mathrm{X}_{\mathrm{Mg}}=\mathrm{Mg} /\left(\mathrm{Fe}^{2+}+\mathrm{Mg}\right)$ 0.80-0.83, содержание $\mathrm{MnO}$ ниже пределов обнаружения (см. Дополнительные материалы). От монтичеллита из типичных кимберлитов [Dongre, Тарре, 2019] он отличается повышенной долей в составе кирштейнитового (17-20 мол. \%) и пониженной форстеритового (0.4-2.1 мол. \%) компонента (рис. 4, а).

Клинопироксен в жилах Большетагнинского массива отсутствует. В кимберлите Бушканайской дайки клинопироксен представлен хромдиопсидом, близким по химическому составу к клинопироксену из оранжеитов (рис. 4, б); вкрапленники клинопироксена в пикрите представлены хромдиопсидом, авгитом и титан-авгитом, а клинопироксен из основной массы пикрита - титанистым авгитом (см. Дополнительные материалы).

Серпентин из псевдоморфоз по оливину и основной массы имеет довольно однородный химический состав: $\mathrm{X}_{\mathrm{Mg}}$ варьируется в основном от 0.92 до 0.99; содержание $\mathrm{Al}_{2} \mathrm{O}_{3}$ составляет до 3.9 мас. \%, СaO преимущественно менее 0.5 мас. \%, в отдельных анализах $1.2-$ 2.3 мас. \%; отмечена примесь $\mathrm{NiO}$ (0.81 мас. \%) (см. Дополнительные материалы).

Флогопит из кимберлита Бушканайской дайки характеризуется умеренно низкими содержаниями $\mathrm{Al}_{2} \mathrm{O}_{3}$ (12.6-13.8 мас. \%), $\mathrm{TiO}_{2}\left(0.7-3.6\right.$ мас. \%) и $\mathrm{FeO}_{\text {общ. }}(4.6-$ 7.4 мас. \%); $\mathrm{X}_{\mathrm{Mg}}=0.84-0.91$, присутствует до 1.2 мас. \% $\mathrm{BaO}$ (см. Дополнительные материалы). На диагностических диаграммах $\mathrm{Al}_{2} \mathrm{O}_{3}-\mathrm{TiO}_{2}$ и $\mathrm{Al}_{2} \mathrm{O}_{3}-\mathrm{FeO}$ (рис. 5) точки состава флогопита располагаются вблизи поля слюд из оранжеитов. Флогопит из пикритов содержит больше $\mathrm{Al}_{2} \mathrm{O}_{3}$ (14.3-16.4 мас. \%), $\mathrm{TiO}_{2}$ (1.9-9.0 мас. \%) и, в целом, менее магнезиальный, $\mathrm{X}_{\mathrm{Mg}}=0.74-0.87$; флогопит 
(a)

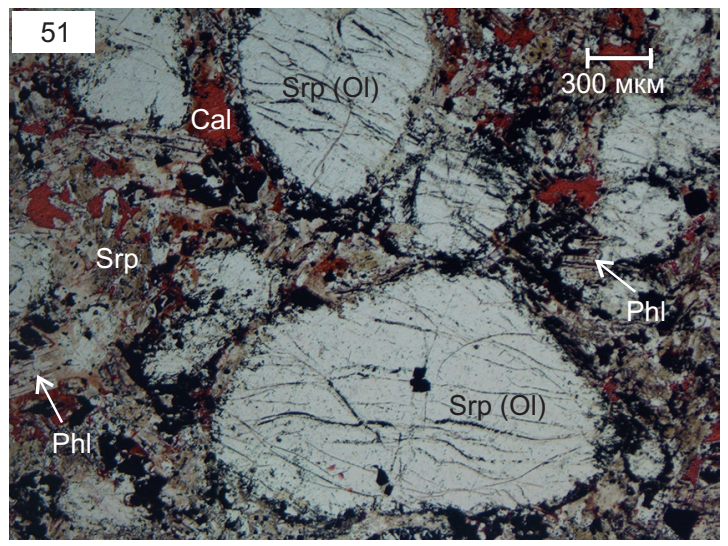

(8)

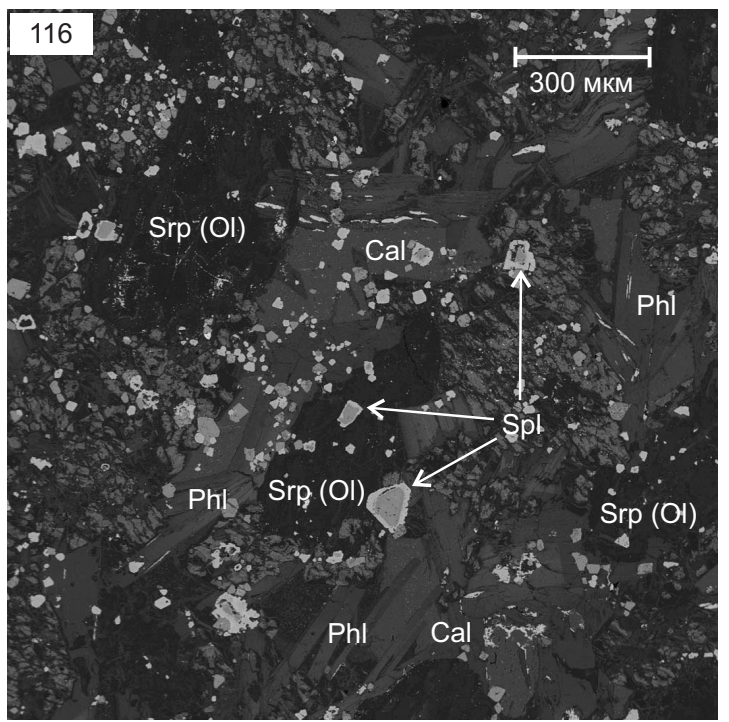

(d)

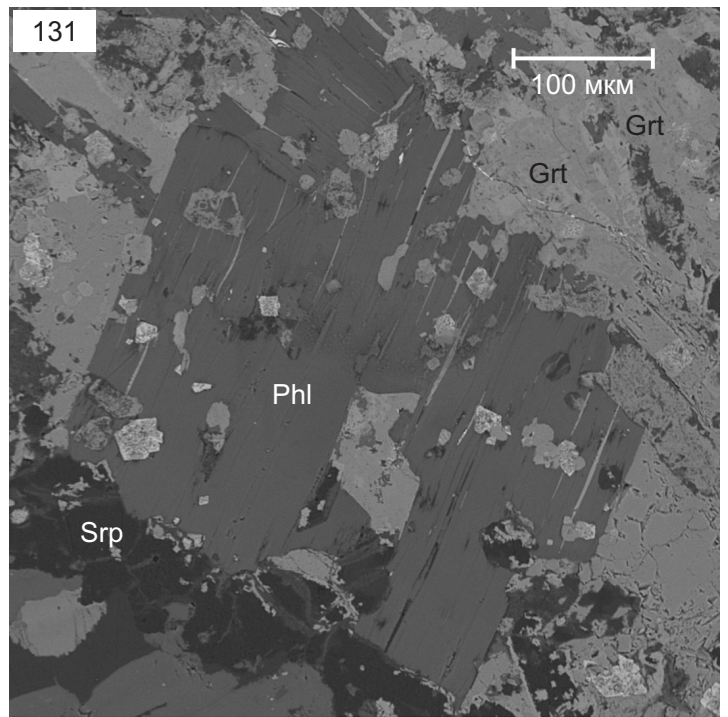

(б)

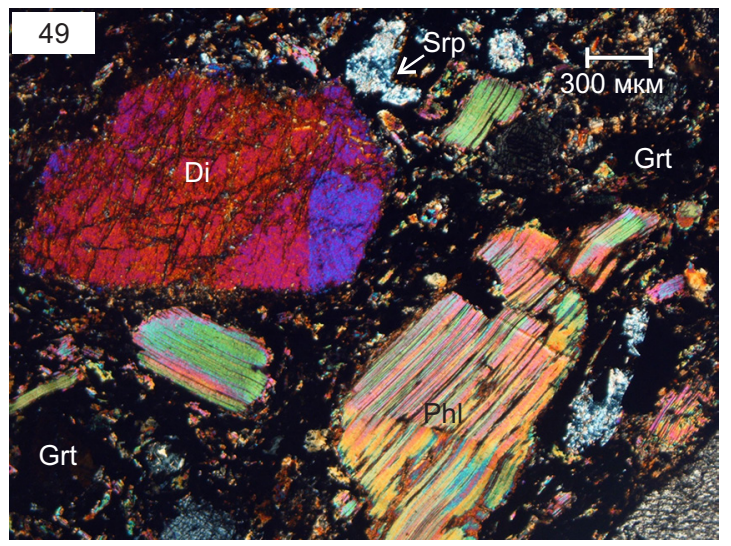

(2)

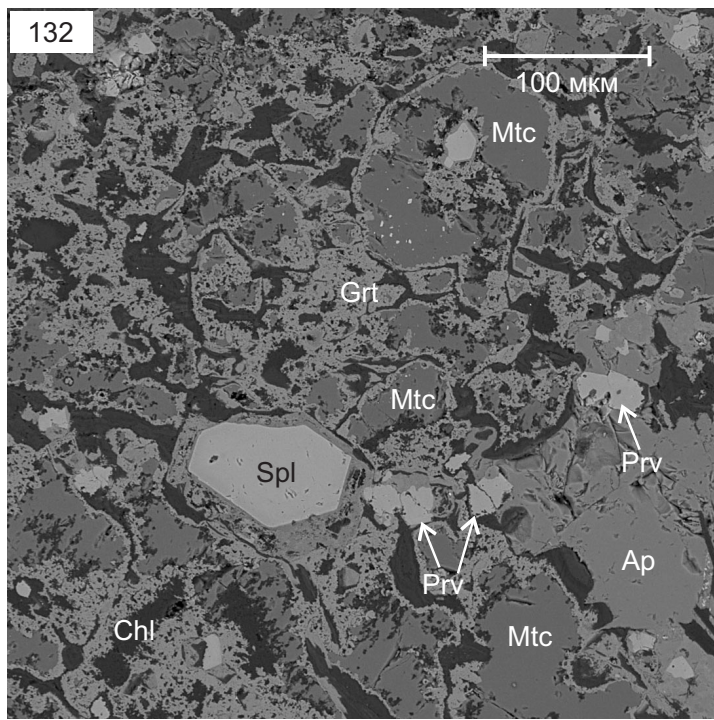

(e)

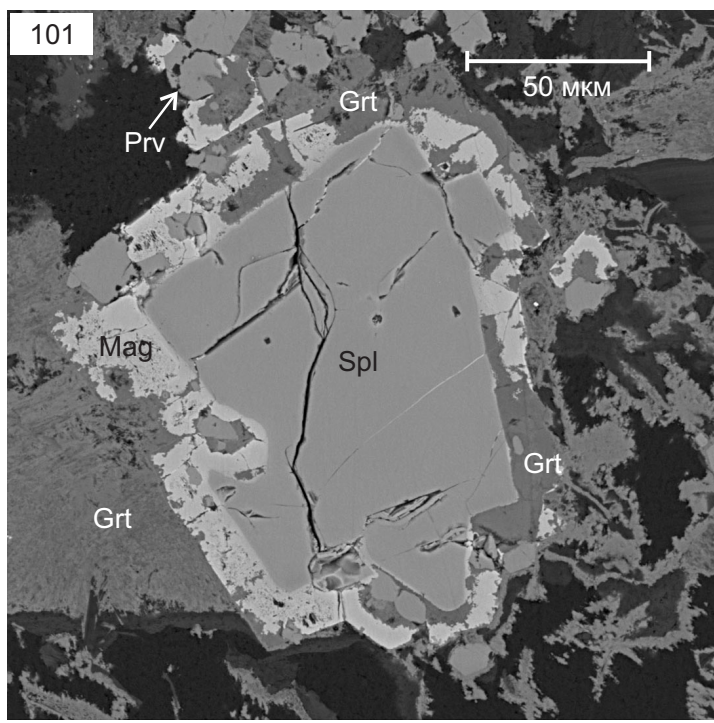

Рис. 3. Взаимоотношения минералов в породах Бушканайской дайки $(a$, б) и беспироксеновых пикритах Большетагнинского массива (в-e) (цифры в прямоугольниках - номера образцов).

Символы минералов: Ap - апатит, Cal - кальцит, Chl - хлорит, Di - диопсид, Grt - гранат, гидрогранат, Mag - магнетит, Mtc монтичеллит, Ol - оливин, Phl - флогопит, Prv - перовскит, Spl - шпинель, Srp - серпентин. $a$, б - фотографии шлифов, в-е изображения в обратнорассеянных электронах.

Fig. 3. Relationships of minerals in the rocks of the Bushkanai dike $(a, \sigma)$ and pyroxene-free picrites of the Bol'shaya Tagna massif $(b-e)$ (numbers in rectangles show sample numbers).

Mineral symbols: Ap - apatite, Cal - calcite, Chl - chlorite, Di - diopside, Grt - garnet, and hydrogarnet, Mag - magnetite, Mtc - monticellite, Ol - olivine, Phl - phlogopite, Prv - perovskite, Spl - spinel, Srp - serpentine. $a$, $\sigma$ - photographs of thin sections; $8-e$ - images in back-scattered electrons. 
Таблица 1. Минеральный состав Бушканайской дайки и жил Большетагнинского массива

Table 1. Mineral composition of the Bushkanai dike and veins of the Bol'shaya Tagna massif

\begin{tabular}{|c|c|c|c|c|}
\hline \multirow{3}{*}{ Порода } & \multicolumn{4}{|c|}{ Минералы } \\
\hline & \multirow{2}{*}{ Вкрапленники } & \multicolumn{3}{|c|}{ Основная масса } \\
\hline & & Раннемагматические & Поздне- и постмагматические & Метаморфические \\
\hline \multicolumn{5}{|c|}{ Бушканайская дайка } \\
\hline Кимберлит & $\begin{array}{l}\text { Оливин (65-70 \%, } \\
\text { замещен), } \\
\text { хромдиопсид }\end{array}$ & $\begin{array}{l}\text { Оливин (замещен), } \\
\text { флогопит, } \\
\text { хромшпинелиды }\end{array}$ & $\begin{array}{l}\text { Хромдиопсид, титаномагнетит, пе- } \\
\text { ровскит, апатит, манганоильменит, } \\
\text { серпентин, кальцит }\end{array}$ & $\begin{array}{l}\text { Хлорит, магнетит, кальцит, андрадит, } \\
\text { диопсид, рутил, гр. кричтонита, титанит, } \\
\text { барит, смизит }(\mathrm{Fe}, \mathrm{Ni})_{9} \mathrm{~S}_{11} \text {, гетит }\end{array}$ \\
\hline $\begin{array}{l}\text { Флогопит- } \\
\text { пироксе- } \\
\text { новые } \\
\text { пикриты }\end{array}$ & $\begin{array}{l}\text { Оливин (5-25 \%, } \\
\text { замещен), } \\
\text { флогопит (3-15\%), } \\
\text { хромдиопсид, авгит } \\
(0-25 \%)\end{array}$ & $\begin{array}{l}\text { Оливин (замещен), } \\
\text { флогопит, титанистый } \\
\text { авгит, хромдиопсид, } \\
\text { хромшпинелиды }\end{array}$ & $\begin{array}{l}\text { Титаномагнетит, перовскит, } \\
\text { апатит, манганоильменит, серпен- } \\
\text { тин, кальцит }\end{array}$ & $\begin{array}{l}\text { Диопсид, тремолит, магнетит, гроссуляр- } \\
\text { андрадит, гидрогранат, хлорит, кальцит, } \\
\text { рутил, гр. кричтонита, титанит, барит, пи- } \\
\text { рит, халькопирит, галенит, смизит, гетит }\end{array}$ \\
\hline \multicolumn{5}{|c|}{ Большетагнинский массив } \\
\hline $\begin{array}{l}\text { Беспиро- } \\
\text { ксеновые } \\
\text { щелочные } \\
\text { пикриты }\end{array}$ & $\begin{array}{l}\text { Оливин }(25-40 \% \text {, } \\
\text { замещен), флогопит } \\
(5-30 \%)\end{array}$ & $\begin{array}{l}\text { Флогопит (10-35 \%), } \\
\text { монтичеллит (ок. } 5 \%) \text {, } \\
\text { оливин (15-20\%, заме- } \\
\text { щен), хромшпинелиды }\end{array}$ & $\begin{array}{l}\text { Титаномагнетит, перовскит, } \\
\text { армолколит, апатит, бадделеит, } \\
\text { кальциртит, манганоильменит, } \\
\text { серпентин, кальцит, титанистый } \\
\text { андрадит }\end{array}$ & $\begin{array}{l}\text { Хлорит, гроссуляр-андрадит, гидрогранат } \\
(10-40 \%), \text { везувиан, магнетит, гр. } \\
\text { кричтонита, титанит, барит, бурбанкит, } \\
\text { стронцианит, миллерит NiS, пирит, халь- } \\
\text { копирит, пентландит, зигенит (Ni, Co })_{3} \mathrm{~S}_{4}, \\
\text { смизит, галенит, сфалерит, ярроуит } \mathrm{Cu}_{9} \mathrm{~S}_{8} \\
\text { халькокит } \mathrm{Cu}_{2} \mathrm{~S} \text {, гетит }\end{array}$ \\
\hline
\end{tabular}

(a)

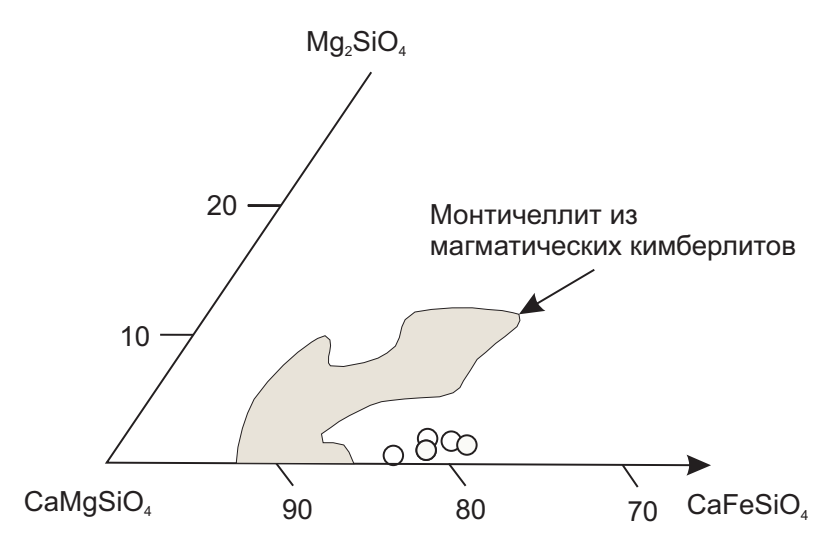

(б)

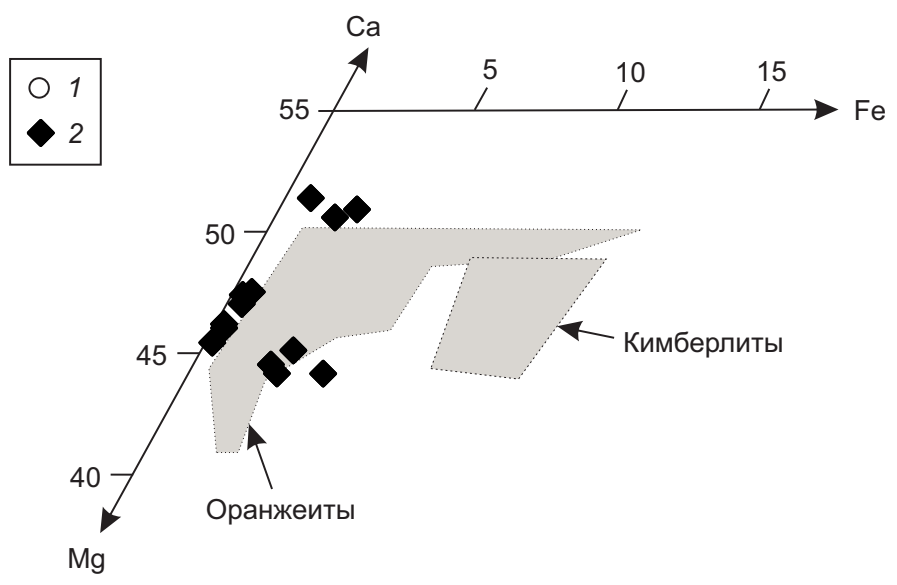

Рис. 4. Диаграммы $\mathrm{CaFeSiO}_{4}-\mathrm{CaMgSiO}_{4}-\mathrm{Mg}_{2} \mathrm{SiO}_{4}$ для монтичеллита [Dongre, Tappe, 2019] (a) и Mg-Fe-Ca (атомные количества) для клинопироксена с полями состава минералов из кимберлитов и оранжеитов [Dongre et al., 2017] (б). 1 - монтичеллит из беспироксенового пикрита Большетагнинского массива; 2 - клинопироксен из кимберлита Бушканайской дайки.

Fig. 4. Diagrams $\mathrm{CaFeSiO}_{4}-\mathrm{CaMgSiO}_{4}-\mathrm{Mg}_{2} \mathrm{SiO}_{4}$ for monticellite [Dongre, Tappe, 2019] (a) and Mg-Fe-Ca (atomic quantities) for clinopyroxene [Dongre et al., 2017] (б) with fields of composition of minerals from kimberlites and orangeites. 1 - monticellite from pyroxene-free picrite of the Bol'shaya Tagna massif; 2 - clinopyroxene from kimberlite of the Bushkanai dike.

из основной массы менее титанистый по сравнению с флогопитом вкрапленников. Краевые зоны вкрапленников и флогопит из основной массы содержат повышенное количество ВаO - 0.85-2.80 мас. \%. На рис. 5 точки состава слюды из пикритов располагаются на тренде слюды из лампрофиров с отклонением к кимберлитовому тренду.

В беспироксеновых пикритах Большетагнинского массива состав флогопита варьируется в разных жилах (рис. 5): количество $\mathrm{TiO}_{2}$ составляет 0.47-2.94 мас. \%, $\mathrm{Al}_{2} \mathrm{O}_{3}-12.4-16.0$ мас. \%, $\mathrm{FeO}_{\text {общ. }}-3.3-6.3$ мас. \%; $\mathrm{X}_{\mathrm{Mg}}-$ 0.86-0.93 (см. Дополнительные материалы). Флогопит содержит варьирующееся, но в целом высокое количе- ство ВаO - 0.6-5.3 мас. \%; химическая зональность не проявлена. В основном слюда имеет состав, сходный с составом слюды в кимберлитах; исключением является жила 101, состав слюды из которой близок к составу слюды из оранжеитов (рис. 5).

Группа шпинели. В породах Бушканайской дайки и беспироксеновых пикритах минералы группы шпинели являются главным образом членами изоморфного ряда хромшпинели - алюмошпинели $(\mathrm{Mg}, \mathrm{Fe})(\mathrm{Cr}, \mathrm{Al})_{2} \mathrm{O}_{4}$ и титаномагнетитом. Хромшпинелиды представлены мелкими (10-150 мкм, редко до 400 мкм) субидиоморфными зернами в основной массе, окруженными каймой титаномагнетита (см. рис. 3, в, е), обычно в ассоциации 
с перовскитом, и нередко внешней каймой титанистого граната (см. рис. 3, е). Во флогопит-пироксеновых пикритах Бушканайской дайки хромшпинелид более интенсивно замещен титаномагнетитом и присутствует лишь в реликтах. Содержание $\mathrm{Cr}_{2} \mathrm{O}_{3}$ в центре зерен 38.0-56.6 мас. \%, $\mathrm{Al}_{2} \mathrm{O}_{3}-8.1-20.0 \%$, $\mathrm{MgO}-9.3-15.0 \%$; хромшпинелид из беспироксеновых пикритов отличается повышенным содержанием $\mathrm{TiO}_{2}$ (см. Дополнительные материалы). На диаграммах $\mathrm{Al}^{3+}-\mathrm{Cr}^{3+}-\mathrm{Fe}^{3+}$ и $\mathrm{Al}^{3+}-\mathrm{Cr}^{3+}-\left(\mathrm{Fe}^{3+}+\mathrm{Ti}^{4+}\right)$ (рис. 6, a, б) наиболее ранние высокохромистые генерации шпинели попадают в поле шпинелей из кимберлитов. Эволюция состава шпинелей (рис. 6, в) отвечает титаномагнетитовому тренду (тренду 2), присущему шпинелям из оранжеитов и айлликитов [Tappe et al., 2005], но встречающемуся иногда и в шпинелях из кимберлитов [Roeder, Schulze, 2008].
Титаномагнетит встречается во флогопит-пироксеновых пикритах Бушканайской дайки и в беспироксеновых пикритах Большетагнинского массива в виде редких крупных (до 5 мм) зерен, но в основном образует каймы вокруг хромшпинелида и присутствует в основной массе (см. Дополнительные материалы). Магнетит встречается в виде мелких зерен (до 30-40 мкм) в основной массе или псевдоморфозах по хромшпинелиду.

Ильменит в жилах Большетагнинского массива и породах Бушканайской дайки встречается в виде редких зерен и представлен манганоильменитом с широкими вариациями содержания MnO: 9-26 мас. \% (см. Дополнительные материалы).

Перовскит широко распространен в основной массе беспироксеновых пикритов и обычен в ассоциации с титаномагнетитом в каймах вокруг хромшпинелидов (a)

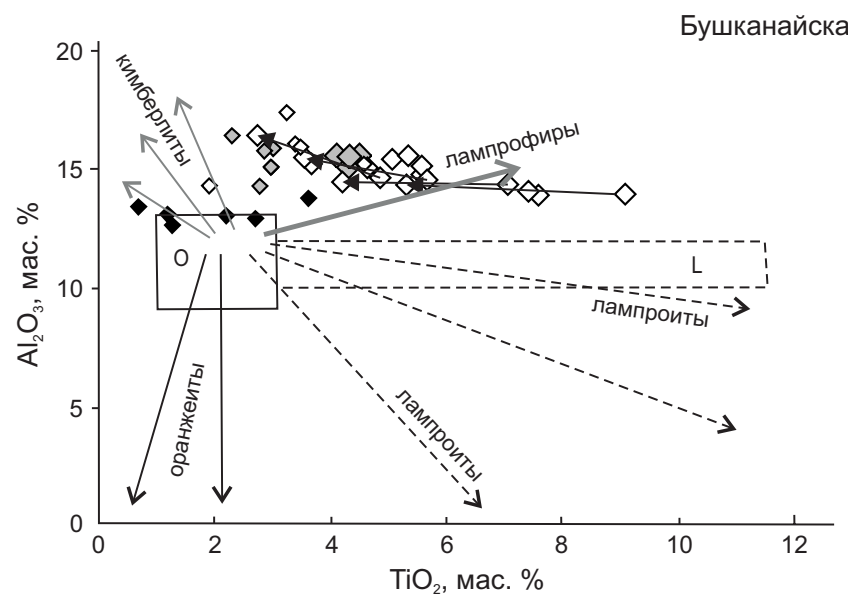

(6)

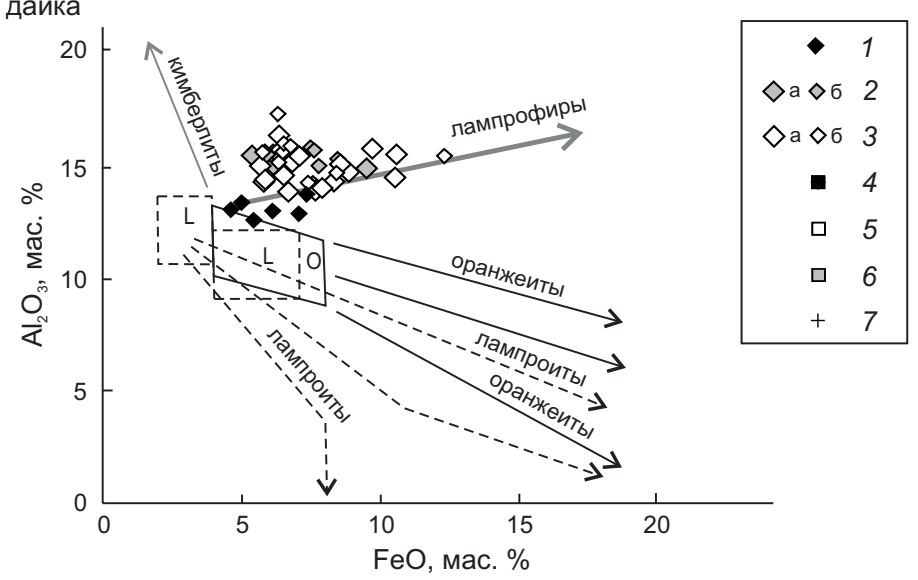

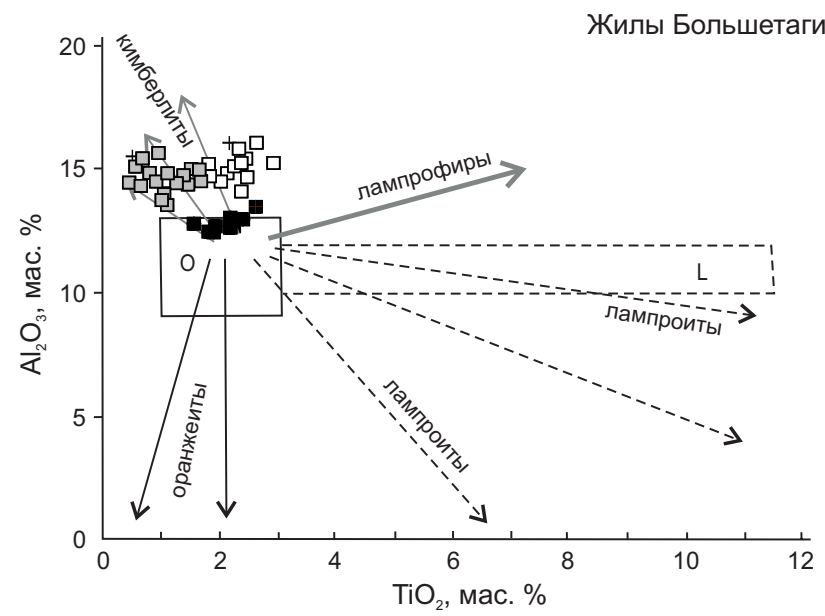

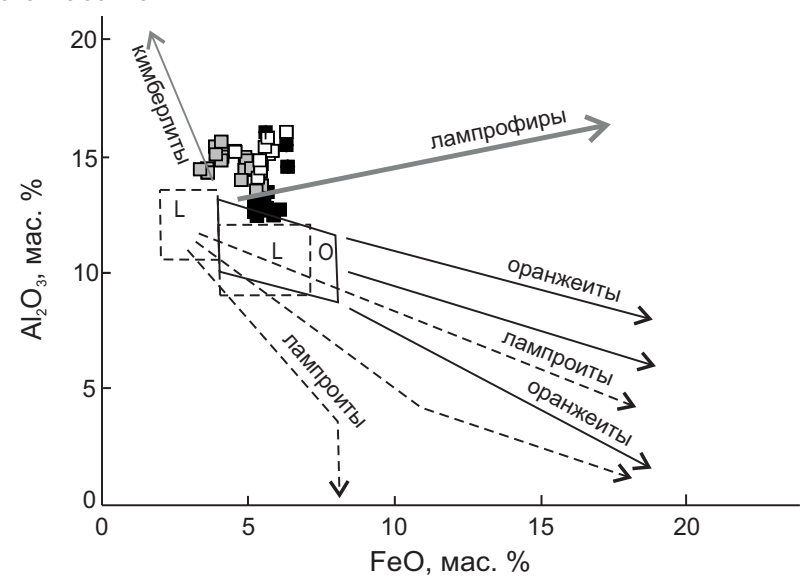

Рис. 5. Диаграммы $\mathrm{Al}_{2} \mathrm{O}_{3}-\mathrm{TiO}_{2}\left(\right.$ a) и $\mathrm{Al}_{2} \mathrm{O}_{3}-\mathrm{FeO}$ (б) для слюды.

Поля для оранжеитов (O), лампроитов (L) и тренды состава слюды по [Mitchell, 1995]. Слюда: 1-3 - из пород Бушканайской дайки: 1 - кимберлита, 2 - бедного слюдой пикрита, 3 - слюдистого пикрита (а - вкрапленники, б - основная масса); стрелки показывают изменение состава от центра к краю вкрапленников; 4-7 - образцы слюды из беспироксеновых пикритов Большетагнинского массива: 4 - 101, 5 - 114 и 115, 6-116, 7 - 131.

Fig. 5. Diagrams $\mathrm{Al}_{2} \mathrm{O}_{3}-\mathrm{TiO}_{2}(a)$ and $\mathrm{Al}_{2} \mathrm{O}_{3}-\mathrm{FeO}$ (б) for mica.

Fields for orangeites (O) and lamproites (L), and mica composition trends after [Mitchell, 1995]. Mica: 1-3-from the rocks of the Bushkanai dike: 1 - kimberlite, 2 - mica-poor picrite, 3 - mica picrite (a - phenocrysts, 6 - bulk); arrows show changes in the composition from the center to the edges of the phenocrysts; 4-7 - mica samples from the pyroxene-free picrites of the Bol'shaya Tagna massif: $4-101$, $5-114$ and $115,6-116,7-131$. 
(см. рис. 3, е); в кимберлите и флогопит-пироксеновых пикритах Бушканайской дайки перовскит более редок. Минерал содержит 1.1-2.9 мас. \% $\mathrm{Ce}_{2} \mathrm{O}_{3}$, до 2 мас. \% $\mathrm{La}_{2} \mathrm{O}_{3}$; перовскит из Бушканайской дайки содержит 1.02.8 мас. \% $\mathrm{Nb}_{2} \mathrm{O}_{5}$, а перовскит из жил Большетагнинского массива - 0.5-1.3 мас. \% SrO.

Карбонаты в жилах Большетагнинского массива и породах Бушканайской дайки представлены кальцитом. Кальцит из кимберлита Бушканайской дайки содержит до 1.0 мас. \% SrO, из жил беспироксеновых пикритов до 2.7 мас. \% SrO. В кальците из беспироксеновых пикритов присутствуют вростки стронцианита и бурбанкита.

Гранат и гидрогранат являются широко распространенными минералами в основной массе пород Бушканайской дайки и беспироксеновых пикритов (см. Дополнительные материалы). Гранат образует каймы вокруг шпинелидов и замещает минералы основной массы. Минерал представлен андрадитом; в каймах вокруг хромшпинелидов он содержит до 11.5 мас. \% $\mathrm{TiO}_{2}$ и до 17.8 мас. \% $\mathrm{Cr}_{2} \mathrm{O}_{3}$ (см. Дополнительные материалы); по химическому составу минерал подобен поздне- и постмагматическим титанистым андрадитам из оранжеитов и ультрамафических лампрофиров [Dongre et al., 2016].

Апатит в породах Бушканайской дайки содержит 1.6-2.9 мас. \% F и до 1.2 мас. \% SrO, в беспироксеновых пикритах Большетагнинского массива 2.0-3.9 мас. \% F и до 2.8 мас. \% $\mathrm{SrO}$.

\section{5. ПЕТРОХИМИЯ И ГЕОХИМИЯ}

Кимберлит Бушканайской дайки характеризуется низким содержанием $\mathrm{SiO}_{2}, \mathrm{Al}_{2} \mathrm{O}_{3}, \mathrm{TiO}_{2}, \mathrm{CaO}, \mathrm{K}_{2} \mathrm{O}$ и $\mathrm{Na}_{2} \mathrm{O}$ при резком преобладании К над $\mathrm{Na}\left(\mathrm{K}_{2} \mathrm{O} / \mathrm{Na}_{2} \mathrm{O}=12\right)$, (a)

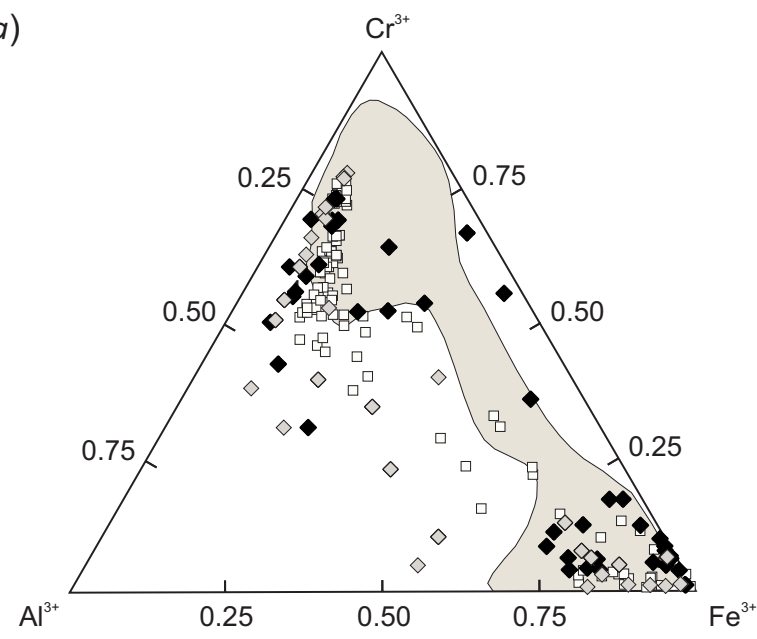

(6)

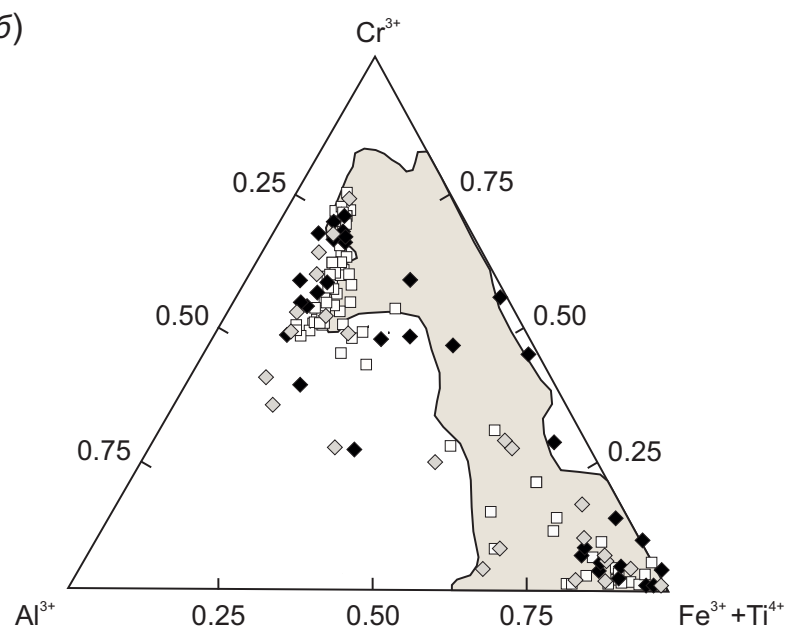

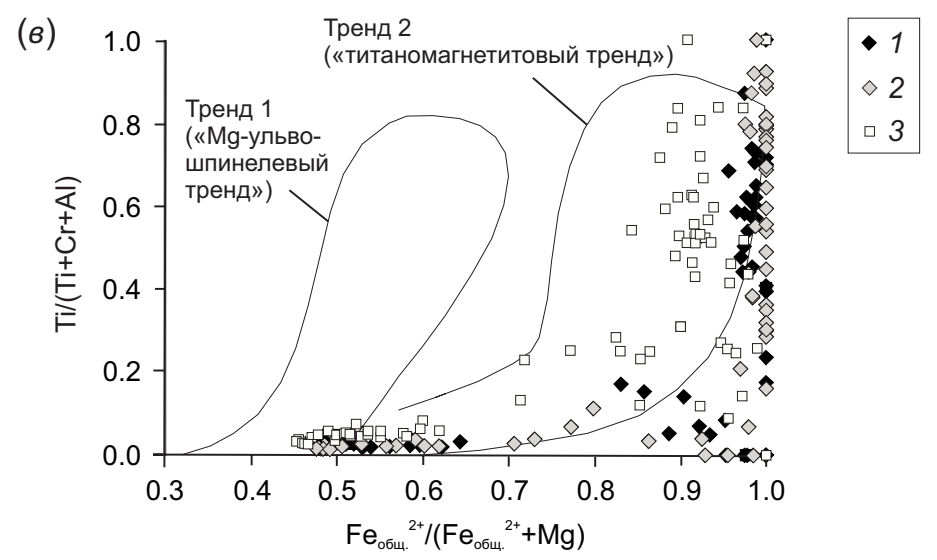

Рис. 6. Диаграммы $\mathrm{Al}^{3+}-\mathrm{Cr}^{3+}-\mathrm{Fe}^{3+}(a), \mathrm{Al}^{3+}-\mathrm{Cr}^{3+}-\left(\mathrm{Fe}^{3+}+\mathrm{Ti}^{4+}\right)$ (б) и $\mathrm{Ti} /(\mathrm{Ti}+\mathrm{Cr}+\mathrm{Al})-\mathrm{Fe}^{2+}{ }_{\text {общ. }}{ }^{+} /\left(\mathrm{Fe}^{2+}{ }_{\text {общ. }}+\mathrm{Mg}\right)($ (в) для шпинелей.

1, 2 - шпинели из кимберлита (1) и флогопит-пироксеновых пикритов (2) Бушканайской дайки; 3 - из беспироксеновых пикритов Большетагнинского массива. Поля на диаграммах - состав шпинелей из кимберлитов по [Barnes, Roeder, 2001] (a) и кимберлитовых пород Якутской кимберлитовой провинции [Bovkun, 2000] (б); тренды состава шпинели для кимберлитов Южной Африки по [Mitchell, 1995].

Fig. 6. Diagrams $\mathrm{Al}^{3+}-\mathrm{Cr}^{3+}-\mathrm{Fe}^{3+}(a), \mathrm{Al}^{3+}-\mathrm{Cr}^{3+}-\left(\mathrm{Fe}^{3+}+\mathrm{Ti}^{4+}\right)$ (б) and $\mathrm{Ti} /(\mathrm{Ti}+\mathrm{Cr}+\mathrm{Al})-\mathrm{Fe}^{2+}{ }_{\text {общ }} /\left(\mathrm{Fe}^{2+}{ }_{\text {общ. }}+\mathrm{Mg}\right)(8)$ for spinels. 1,2 - spinels from kimberlite (1) and phlogopite-pyroxene picrites (2) of the Bushkanai dike; 3 - spinels from the pyroxene-free picrites of the Bol'shaya Tagna massif. The fields in the diagrams show the compositions of spinels from kimberlites (after [Barnes, Roeder, 2001]) (a) and the kimberlite rocks of the Yakutian kimberlite province [Bovkun, 2000] (б); spinel composition trends for the South African kimberlites (after [Mitchell, 1995]). 
умеренным содержанием $\mathrm{FeO}_{\text {общ. }} \mathrm{CO}_{2}$, высоким $\mathrm{MgO}$ и величиной Mg\# 0.86 (табл. 2, анализ 1). Для оценки степени загрязнения расплава использовался индекс загрязнения C.I. и отношение $\mathrm{Si} / \mathrm{Mg}$, значения которых больше соответственно 1.5 и 1.2 подразумевают загрязнение материалом земной коры [Chalapathi Rao, 2005]. Низкие значения C.I. (1.1) и Si/Mg (0.7) в кимберлите Бушканайской дайки позволяют считать породу неконтаминированной. По химическому составу порода является низкотитанистой, низкокалиевой, магнезиально-железистой [Bogatikov et al., 2009; Kostrovitsky et al., 2007]; на петрохимических диаграммах (рис. 7) [Becker et al., 2007] точка состава располагается в области перекрытия полей южно-африканских кимберлитов I и II группы.

Пикриты Бушканайской дайки имеют сходный химический состав, но богатый слюдой пикрит (обр. 49) содержит больше $\mathrm{SiO}_{2}$ и $\mathrm{K}_{2} \mathrm{O}$ (табл. 2, анализы 2, 3). По сравнению с кимберлитом, в пикритах выше содержание $\mathrm{Al}_{2} \mathrm{O}_{3}, \mathrm{TiO}_{2}, \mathrm{CaO}$, щелочей, $\mathrm{P}_{2} \mathrm{O}_{5}, \mathrm{Fe}_{2} \mathrm{O}_{3}$ и значительно ниже MgO.

Беспироксеновые пикриты Большетагнинского массива (табл. 2, анализы 4-8; рис. 7) характеризуются широкими вариациями содержаний $\mathrm{SiO}_{2}$ (23.6-33.2 мас. \%), MgO (16.1-24.1 мас. \%) и СaO (12.4-22.8 мас. \%); Mg\#= 0.73-0.80. По сравнению с кимберлитом Бушканайской дайки, в беспироксеновых пикритах выше содержание $\mathrm{Al}_{2} \mathrm{O}_{3}, \mathrm{TiO}_{2}, \mathrm{CaO}, \mathrm{K}_{2} \mathrm{O}, \mathrm{P}_{2} \mathrm{O}_{5}, \mathrm{MnO}$ и значительно ниже $\mathrm{MgO}$ (табл. 2). Содержание $\mathrm{Na}_{2} \mathrm{O}$ в беспироксеновых пикритах низкое, 0.01-0.05 мас. \%; отношение $\mathrm{K}_{2} \mathrm{O} / \mathrm{Na}_{2} \mathrm{O}$ выше, чем в кимберлите (за исключением обр. 132 с сильно хлоритизированным флогопитом). По химическому составу породы соответствуют железотитанистому низкокалиевому петрохимическому типу кимберлитов северных полей Якутской провинции с убогой алмазоносностью [Kostrovitsky et al., 2007].
Наиболее низкие значения C.I. (1.2) и $\mathrm{Si} / \mathrm{Mg}(0.8)$ присущи образцу 116 (табл. 2, анализ 6), что позволяет предполагать отсутствие загрязнения расплава коровым материалом; в других жилах C.I.=1.6-2.1, что указывает на возможную контаминацию коровым материалом или высокоглиноземистыми породами Большетагнинского массива. Намечается отрицательная корреляция между содержаниями $\mathrm{CaO}$ и $\mathrm{SiO}_{2}$ (рис. 7, в), отражающая изначальное присутствие в беспироксеновых пикритах карбонатной составляющей, в то же время аномальное количество $\mathrm{CO}_{2}$ в обр. 114 из эндоконтактовой зоны жилы среди карбонатита указывает на ассимиляцию ультраосновным расплавом вмещающих карбонатитов.

На диаграмме $\mathrm{TiO}_{2}-\mathrm{K}_{2} \mathrm{O}$ (рис. 7, в) точки анализов беспироксеновых пикритов располагаются в поле кимберлитов группы I, однако на других диаграммах (рис. 7) в это поле попадает только точка наименее контаминированной породы (обр. 116).

Кимберлит Бушканайской дайки характеризуется высокими концентрациями $\mathrm{Ni}, \mathrm{Co}, \mathrm{Cr}$, но низкими V и $\mathrm{Cu}$ (табл. 2). Флогопит-пироксеновые пикриты Бушканайской дайки, напротив, имеют низкое содержание $\mathrm{Ni}, \mathrm{Cr}, \mathrm{Co}$ (табл. 2; рис. 8). В беспироксеновых пикритах Большетагнинского массива содержание $\mathrm{Ni}, \mathrm{Co}, \mathrm{Cr}$ варьируется, снижаясь с уменьшением содержания $\mathrm{MgO}$, a содержание $\mathrm{V}$ повышено по сравнению с кимберлитом (табл. 2; рис. 8).

Кимберлит Бушканайской дайки имеет низкие концентрации $\mathrm{Rb}$ и Ва (табл. 2, анализ 1). В беспироксеновых пикритах Большетагнинского массива (табл. 2, анализы 4-8) содержание этих элементов в 3-8 раз выше, чем в кимберлите, за исключением обр. 132 с хлоритизированным флогопитом (анализ 8). Содержание Sr в беспироксеновых пикритах существенно превышает содержание Sr в кимберлите и флогопит-пироксеновых пикритах Бушканайской дайки.

Таблица 2. Химический состав пород Бушканайской дайки и Большетагнинского массива

Table 2. Chemical composition of the rocks of the Bushkanai dike and the Bol'shaya Tagna massif

\begin{tabular}{|c|c|c|c|c|c|c|c|c|}
\hline \multirow{3}{*}{$\begin{array}{l}\text { Компоненты, } \\
\text { мас. \% }\end{array}$} & \multicolumn{3}{|c|}{ Бушканайская дайка } & \multicolumn{5}{|c|}{ Большетагнинский массив } \\
\hline & 1 & 2 & 3 & 4 & 5 & 6 & 7 & 8 \\
\hline & $51^{*}$ & $47^{*}$ & $49^{*}$ & 101 & 114 & $116^{*}$ & 131 & $132^{*}$ \\
\hline $\mathrm{SiO}_{2}$ & 33.87 & 30.79 & 35.73 & 33.24 & 23.62 & 28.42 & 29.79 & 29.25 \\
\hline $\mathrm{TiO}_{2}$ & 0.43 & 2.49 & 2.50 & 2.11 & 2.28 & 2.02 & 3.25 & 1.98 \\
\hline $\mathrm{Al}_{2} \mathrm{O}_{3}$ & 2.03 & 6.23 & 7.61 & 4.65 & 4.44 & 3.28 & 5.58 & 4.25 \\
\hline $\mathrm{Fe}_{2} \mathrm{O}_{3}$ & 7.79 & 11.43 & 8.57 & 9.70 & 6.40 & 9.22 & 8.68 & 8.53 \\
\hline $\mathrm{FeO}$ & 2.57 & 2.94 & 3.20 & 2.00 & 3.43 & 3.90 & 2.75 & 2.16 \\
\hline $\mathrm{MnO}$ & 0.13 & 0.26 & 0.15 & 0.29 & 0.27 & 0.15 & 0.20 & 0.21 \\
\hline $\mathrm{MgO}$ & 33.28 & 16.45 & 17.38 & 23.75 & 16.49 & 24.08 & 16.08 & 19.20 \\
\hline $\mathrm{CaO}$ & 5.25 & 17.14 & 14.52 & 12.86 & 22.75 & 12.36 & 19.25 & 20.45 \\
\hline $\mathrm{Na}_{2} \mathrm{O}$ & 0.02 & 0.07 & 0.12 & 0.01 & 0.04 & 0.05 & 0.05 & 0.02 \\
\hline $\mathrm{K}_{2} \mathrm{O}$ & 0.23 & 1.06 & 1.95 & 0.45 & 0.81 & 1.33 & 1.13 & 0.06 \\
\hline $\mathrm{P}_{2} \mathrm{O}_{5}$ & 0.18 & 0.46 & 0.37 & 0.77 & 0.24 & 0.81 & 0.52 & 0.76 \\
\hline $\mathrm{H}_{2} \mathrm{O}^{-}$ & 0.20 & 0.23 & 0.20 & 0.20 & 0.20 & 0.19 & 0.13 & 0.21 \\
\hline П.п.п. & 11.13 & 5.67 & 5.06 & 8.58 & 5.98 & 7.98 & 6.20 & 7.75 \\
\hline $\mathrm{F}$ & 0.16 & 0.16 & 0.19 & 0.30 & 0.18 & 0.35 & 0.39 & 0.25 \\
\hline$-O(F)$ & 0.07 & 0.07 & 0.08 & 0.13 & 0.08 & 0.15 & 0.16 & 0.11 \\
\hline Сумма & 100.37 & 99.89 & 99.86 & 99.87 & 98.91 & 100.18 & 99.62 & 98.33 \\
\hline
\end{tabular}


Таблица 2 (продолжение)

Table 2 (continued)

\begin{tabular}{|c|c|c|c|c|c|c|c|c|}
\hline \multirow{3}{*}{$\begin{array}{l}\text { Компоненты, } \\
\text { мас. \% }\end{array}$} & \multicolumn{3}{|c|}{ Бушканайская дайка } & \multicolumn{5}{|c|}{ Большетагнинский массив } \\
\hline & 1 & 2 & 3 & 4 & 5 & 6 & 7 & 8 \\
\hline & $51^{*}$ & $47^{*}$ & $49 *$ & 101 & 114 & $116^{*}$ & 131 & $132^{*}$ \\
\hline Mg\# & 0.86 & 0.69 & 0.74 & 0.80 & 0.77 & 0.78 & 0.73 & 0.78 \\
\hline $\mathrm{K}_{2} \mathrm{O} / \mathrm{Na}_{2} \mathrm{O}$ & 12 & 15 & 16 & 45 & 20 & 27 & 23 & 3 \\
\hline$(\mathrm{Na}+\mathrm{K}) / \mathrm{Al}$ & 0.14 & 0.20 & 0.30 & 0.11 & 0.21 & 0.46 & 0.23 & 0.02 \\
\hline C.I. & 1.1 & 2.1 & 2.3 & 1.6 & 1.6 & 1.2 & 2.1 & 1.7 \\
\hline $\mathrm{Si} / \mathrm{Mg}$ & 0.7 & 1.3 & 1.4 & 0.9 & 1.0 & 0.8 & 1.2 & 1.0 \\
\hline \multicolumn{9}{|l|}{ Элементы, ppm } \\
\hline $\mathrm{Li}$ & 14 & 32 & 44 & 20 & 28 & 10 & 31 & 17 \\
\hline $\mathrm{V}$ & 66 & 180 & 180 & 250 & 170 & 300 & 190 & 260 \\
\hline $\mathrm{Cr}$ & 2000 & 950 & 1200 & 2200 & 1100 & 1400 & 840 & 1500 \\
\hline Co & 110 & 75 & 67 & 82 & 55 & 87 & 52 & 61 \\
\hline $\mathrm{Ni}$ & 1200 & 270 & 350 & 700 & 460 & 850 & 260 & 440 \\
\hline $\mathrm{Cu}$ & 38 & 38 & 75 & 100 & 31 & 91 & 84 & 65 \\
\hline $\mathrm{Zn}$ & 59 & 96 & 63 & 75 & 160 & 64 & 79 & 69 \\
\hline $\mathrm{Rb}$ & 9.2 & 33 & 75 & 31 & 29 & 66 & 69 & 6 \\
\hline $\mathrm{Sr}$ & 285 & 334 & 262 & 410 & 1100 & 1061 & 990 & 1141 \\
\hline Y & 6.9 & 14 & 12 & 13 & 62 & 15 & 15 & 20 \\
\hline $\mathrm{Nb}$ & 36 & 136 & 60 & 130 & 240 & 69 & 180 & 152 \\
\hline Cs & 2.2 & 2.9 & 2.4 & - & - & 0.98 & - & 0.17 \\
\hline $\mathrm{Ba}$ & 140 & 477 & 866 & 740 & 750 & 1073 & 1300 & 116 \\
\hline $\mathrm{La}$ & 32.3 & 120.3 & 70.3 & 47 & 160 & 61.9 & 95 & 113.6 \\
\hline $\mathrm{Ce}$ & 56.6 & 253.6 & 139.0 & 120 & 280 & 120.3 & 170 & 216.8 \\
\hline $\operatorname{Pr}$ & 6.2 & 29.2 & 16.5 & - & - & 14.0 & - & 24.6 \\
\hline $\mathrm{Nd}$ & 19.2 & 96.6 & 57.9 & 35 & 210 & 52.5 & 100 & 89.5 \\
\hline $\mathrm{Sm}$ & 3.4 & 14.6 & 9.4 & - & - & 8.4 & - & 13.6 \\
\hline $\mathrm{Eu}$ & 0.83 & 3.5 & 2.4 & - & - & 2.2 & - & 3.4 \\
\hline Gd & 2.2 & 8.8 & 5.8 & - & - & 5.9 & - & 9.4 \\
\hline $\mathrm{Tb}$ & 0.28 & 1.0 & 0.70 & - & - & 0.74 & - & 1.1 \\
\hline Dy & 1.4 & 4.3 & 3.1 & - & - & 3.6 & - & 5.1 \\
\hline $\mathrm{Tm}$ & 0.09 & 0.15 & 0.12 & - & - & 0.15 & - & 0.20 \\
\hline $\mathrm{Yb}$ & 0.52 & 0.81 & 0.72 & - & - & 0.90 & - & 1.1 \\
\hline $\mathrm{Lu}$ & 0.08 & 0.11 & 0.11 & - & - & 0.12 & - & 0.14 \\
\hline $\mathrm{Hf}$ & 1.6 & 5.0 & 4.9 & - & - & 4.6 & - & 4.4 \\
\hline $\mathrm{Ta}$ & 1.8 & 12.5 & 5.0 & 7.0 & 6.4 & 3.4 & 8.9 & 9.7 \\
\hline $\mathrm{Pb}$ & 0.09 & 14 & 4.5 & 9.1 & 57 & 3.7 & 16 & 8.0 \\
\hline $\mathrm{Th}$ & 2.9 & 19 & 7.2 & 7.8 & 130 & 5.0 & 14 & 11 \\
\hline $\mathrm{U}$ & 0.72 & 2.5 & 1.1 & 4 & 22 & 1.4 & 4.4 & 4.2 \\
\hline $\mathrm{Nb} / \mathrm{Th}$ & 12 & 7 & 8 & 17 & 2 & 14 & 13 & 13 \\
\hline $\mathrm{Nb} / \mathrm{U}$ & 50 & 54 & 53 & 33 & 11 & 48 & 41 & 36 \\
\hline $\mathrm{Nb} / \mathrm{Y}$ & 5 & 10 & 5 & 10 & 4 & 5 & 12 & 8 \\
\hline Th/Ce & 0.05 & 0.07 & 0.05 & 0.07 & 0.46 & 0.04 & 0.08 & 0.05 \\
\hline $\mathrm{Zr} / \mathrm{Nb}$ & 1.9 & 1.4 & 3.3 & 2.2 & 2.3 & 3.6 & 1.1 & 1.3 \\
\hline $\mathrm{La} / \mathrm{Yb}$ & 62 & 148 & 98 & - & - & 69 & - & 103 \\
\hline $\mathrm{La} / \mathrm{Nb}$ & 0.09 & 0.09 & 1.2 & 0.4 & 0.7 & 0.9 & 0.5 & 0.8 \\
\hline $\mathrm{Ce} / \mathrm{Y}$ & 8 & 18 & 12 & 9 & 5 & 8 & 11 & 11 \\
\hline $\mathrm{Ba} / \mathrm{Th}$ & 48 & 25 & 120 & 95 & 8 & 215 & 93 & 11 \\
\hline $\mathrm{Ba} / \mathrm{Nb}$ & 4 & 4 & 14 & 6 & 3 & 16 & 7 & 0.8 \\
\hline $\mathrm{Ba} / \mathrm{La}$ & 4 & 4 & 12 & 16 & 5 & 17 & 14 & 1.0 \\
\hline
\end{tabular}

Примечание. 1-3 - Бушканайская дайка: 1 - кимберлит, 2, 3 - флогопит-пироксеновые пикриты (2 - малослюдистый, 3 - слюдистый); 4-8 -

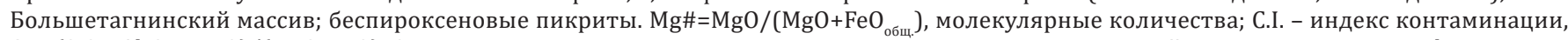
C.I. $=\left(\mathrm{SiO}_{2}+\mathrm{Al}_{2} \mathrm{O}_{3}+\mathrm{Na}_{2} \mathrm{O}\right) /\left(\mathrm{MgO}+\mathrm{K}_{2} \mathrm{O}\right)$. Определение петрогенных компонентов выполнено методом «мокрой» химии, Li - методом фотометрии пламени; в пробах, отмеченных в таблице*, содержания $\mathrm{V}, \mathrm{Cr}, \mathrm{Co}, \mathrm{Ni}, \mathrm{Cu}, \mathrm{Zn}$ определялись методом рентгенофлуоресцентного анализа, прочих элементов - методом ICP-MS, в остальных пробах определения микроэлементов выполнены методом рентгенофлуоресцентного анализа. Прочерк - данные отсутствуют. Анализы выполнены в ЦКП «Геодинамика и геохронология», ИЗК СО РАН (г. Иркутск).

Note. 1-3 - Bushkanai dike: 1 - kimberlite, 2, 3 - phlogopite-pyroxene picrites (2 - low mica, 3- mica); 4-8 - pyroxene-free picrites of the Bol'shaya Tagna massif. $\mathrm{Mg} \#=\mathrm{MgO} /\left(\mathrm{MgO}+\mathrm{FeO}_{\text {общ. }}\right)$, molecular amounts; C.I. - contamination index, $\mathrm{C} . \mathrm{I} .=\left(\mathrm{SiO}_{2}+\mathrm{Al}_{2} \mathrm{O}_{3}+\mathrm{Na}_{2} \mathrm{O}\right) /\left(\mathrm{MgO}+\mathrm{K}_{2} \mathrm{O}\right)$. The wet chemistry method was used to determined petrogenic components. Flame photometry was used to determine Li contents. For the samples marked with * in the table, the X-ray fluorescence analysis was used to determine V, Cr, Co, Ni, Cu, and $\mathrm{Zn}$ concentrations, and other elements were determined by ICP-MS. In other samples, trace elements were determined by the X-ray fluorescence analysis. Dash - no data available. The analyses were performed at the Geodynamics and Geochronology Center, Institute of the Earth's Crust SB RAS (Irkutsk). 
Кимберлит Бушканайской дайки характеризуется низкими концентрациями высокозарядных и легких редкоземельных элементов (табл. 2). В беспироксеновых пикритах Большетагнинского массива содержание этих элементов в несколько раз выше при сравнительно небольших вариациях (табл. 2). Наиболее высокое содержание $\mathrm{Zr}, \mathrm{Th}, \mathrm{U}, \mathrm{Y}, \mathrm{La}, \mathrm{Ce}, \mathrm{Pb}$ имеет пикрит из эндоконтактовой зоны жилы среди карбонатитов (обр. 114). По соотношениям $\mathrm{Ba} / \mathrm{Nb}-\mathrm{La} / \mathrm{Nb}$ беспироксеновые пикриты близки к кимберлитам группы I (рис. 8, в), но отличаются пониженными Се/Pb (рис. 8, г).

Спектры микроэлементов (рис. 9) для кимберлита Бушканайской дайки демонстрируют характерное для кимберлитов обогащение наиболее несовместимыми высокозарядными редкими элементами и легкими редкоземельными элементами $\left(\mathrm{La}_{\mathrm{N}} / \mathrm{Yb}_{\mathrm{N}}=45\right)$, а также минимумы по Rb, K, Ti, Hf и менее выраженный минимум по Sr, что присуще кимберлитам группы I [Le Roex et al., 2003; Becker, Le Roex, 2006]. Спектр микроэлементов демонстрирует сходство (за исключением Cs) с распределением микроэлементов в алмазоносных кимберлитах Якутской провинции [Kostrovitsky et al., 2007], однако уровень обогащенности наиболее несо- вместимыми элементами в кимберлите Бушканайской дайки значительно ниже, чем в южно-африканских и якутских кимберлитах, проявлена истощенность наиболее несовместимыми элементами левой части спектра, а тяжелые редкоземельные элементы показывают умеренное фракционирование, $\mathrm{Gd}_{\mathrm{N}} / \mathrm{Yb}_{\mathrm{N}}=3.5$. Спектры флогопит-пироксеновых пикритов Бушканайской дайки показывают более высокий уровень обогащенности наиболее несовместимыми элементами, легкими редкоземельными элементами относительно тяжелых $\left(\mathrm{La}_{\mathrm{N}} / \mathrm{Yb}_{\mathrm{N}}=70-107\right)$, глубокие минимумы по Sr и $\mathrm{P}$, минимум по $\mathrm{U}$ и максимум по $\mathrm{Pb}$ для малослюдистого пикрита.

Беспироксеновые пикриты Большетагнинского массива по сравнению с кимберлитом Бушканайской дайки характеризуются повышенными концентрациями редкоземельных элементов и их более фракционированным распределением: $\mathrm{La}_{\mathrm{N}} / \mathrm{Yb}_{\mathrm{N}}=49-77, \mathrm{Gd}_{\mathrm{N}} / \mathrm{Yb}_{\mathrm{N}}=5.4-$ 7.3. Мультиэлементный спектр неконтаминированного образца 116 существенно отличается от спектров кимберлитов. В образце 132 монтичеллитового беспироксенового пикрита обедненность $\mathrm{Rb}, \mathrm{Ba}$ и К обусловлена сильной хлоритизацией флогопита (рис. 9).
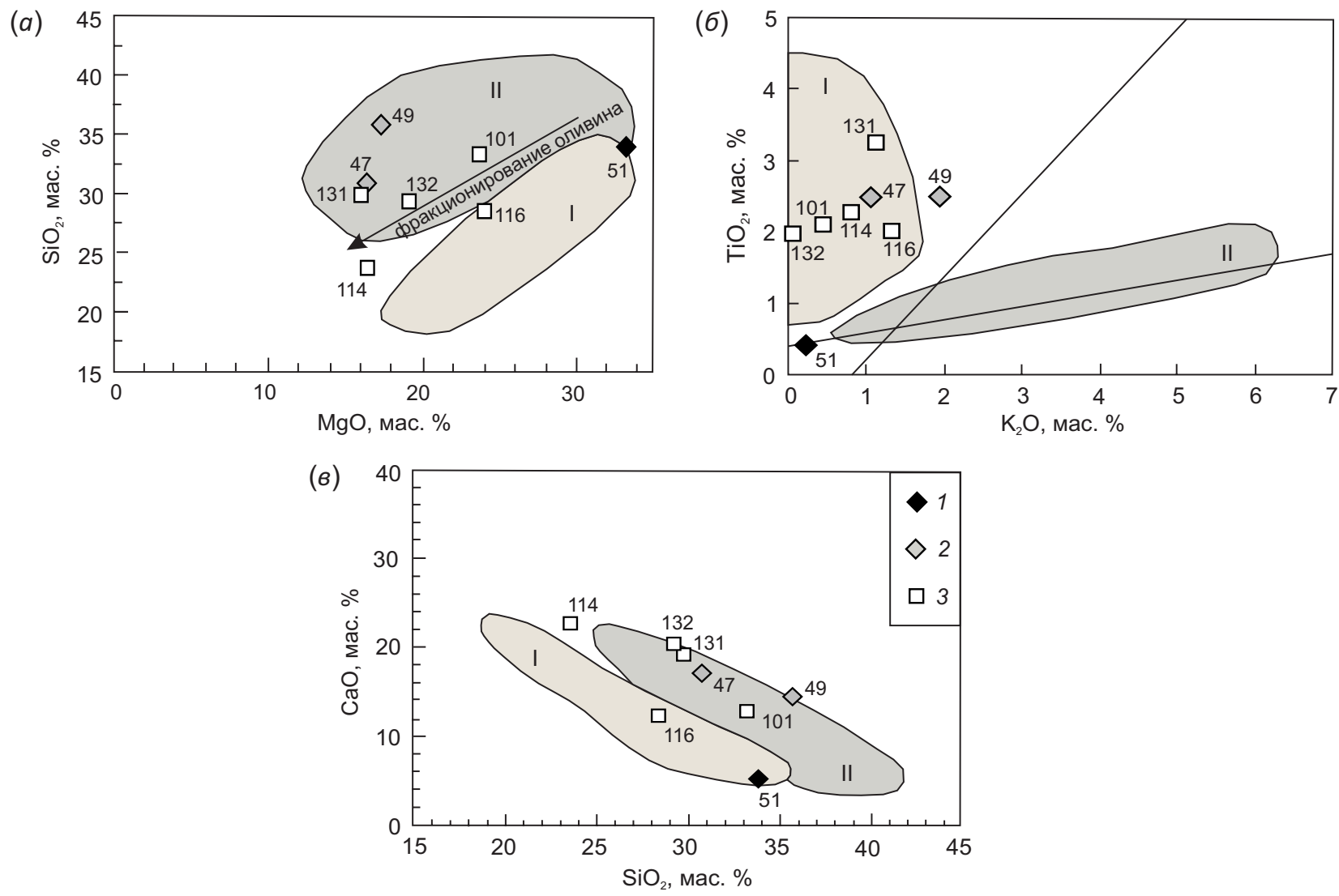

Рис. 7. Вариации петрогенных оксидов в породах Бушканайской дайки и в беспироксеновых пикритах Большетагнинского массива.

Здесь и далее на рисунках: 1,2 - Бушканайская дайка: 1 - кимберлит, 2 - флогопит-пироксеновые пикриты; 3 - беспироксеновые пикриты Большетагнинского массива. Поля кимберлитов I и II группы Южной Африки по [Becker et al., 2007].

Fig. 7. Variations of petrogenic oxides in the rocks of the Bushkanai dike and the pyroxene-free picrites of the Bol'shaya Tagna massif. In Fig. 7 and other figures below: 1,2 - Bushkanai dike: 1 - kimberlite, 2 - phlogopite-pyroxene picrites; 3 - pyroxene-free picrites of the Bol'shaya Tagna massif. Fields of the South African kimberlites of groups I and II after [Becker et al., 2007]. 


\section{6. ОБСУЖДЕНИЕ}

Несмотря на определенное сходство беспироксеновых пикритов с кимберлитами (кимберлитами группы I, по [Mitchell, 1995]) по петрографическим особенностям (неравномерно-зернистая текстура, преобладание серпентинизированного оливина и серпентина с переменным количеством флогопита и кальцита), для них характерны и существенные отличия от кимберлитов. Прежде всего, это отсутствие макро- и мегакрист пиропового граната, Mg-ильменита, $\mathrm{Cr}$-диопсида или других типов клинопироксена, энстатита, которые, как полагают, являются составными частями захваченных из мантии ксенолитов [Goloburdina, 2017; Petrographic Code ..., 2008; Le Maitre, 2005; Scott Smith et al., 2018]. Макрокристы хромдиопсида обнаружены только в кимберлите Бушканайской дайки. Возможно, отсутствие этих минералов в изученных породах связано с недостаточным объемом проанализированного материала.

Кроме того, беспироксеновые пикриты Большетагнинского массива отличаются от кимберлита Бушканайской дайки меньшим количеством оливина, присутствием монтичеллита, большим количеством постмагматического андрадитового граната и гидрограната. Эти признаки указывают на то, что кристаллизация беспироксеновых пикритов происходила из более эволюционированного ультраосновного расплава, более богатого кальцием, при пониженном парциальном давлении $\mathrm{CO}_{2}$, а обилие гидрограната (и везувиана в некоторых жилах) связано с воздействием на породы на постмагматической стадии флюида с высоким отношением $\mathrm{H}_{2} \mathrm{O} / \mathrm{CO}_{2}$.

Слюда и хромшпинелиды из беспироксеновых пикритов Большетагнинского массива имеют химический состав, сходный с составом минералов из кимберлитов (см. рис. 5; 6, а, б). Однако эволюция состава шпинели отвечает титаномагнетитовому тренду, в большей мере присущему оранжеитам и ультрамафическим лампрофирам, чем кимберлитам (см. рис. 6, в); это может быть обусловлено кристаллизацией флогопита на ранних стадиях; значение $\mathrm{Cr} \#=\mathrm{Cr} /(\mathrm{Al}+\mathrm{Cr})$ в центре зерен хромшпинели составляет 0.57-0.81, что характерно для айлликитов, а не для оранжеитов (Cr\#>0.85) [Tарpe et al., 2005]. Общая направленность изменения состава слюды в беспироксеновых пикритах отвечает лампрофировому тренду, а не кимберлитовому (см. рис. 5). Шорломит-андрадитовый гранат также не характерен для кимберлитов, но встречается в оранжеитах и ультрамафических лампрофирах [Dongre et al., 2016]. Отличием от кимберлитов является также присутствие (a)

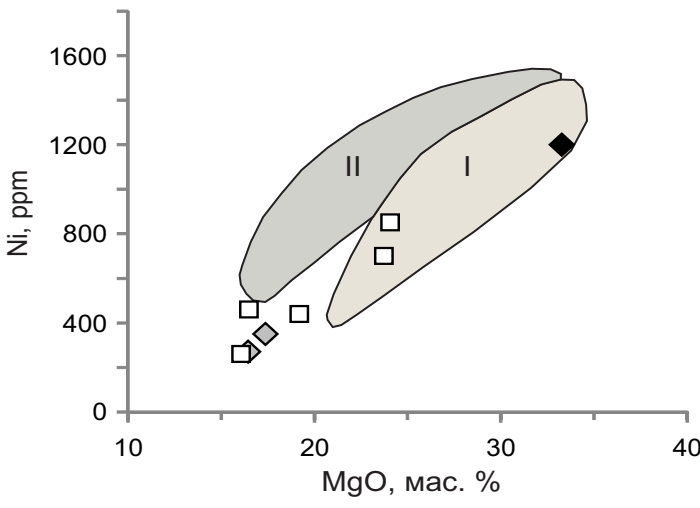

(в)

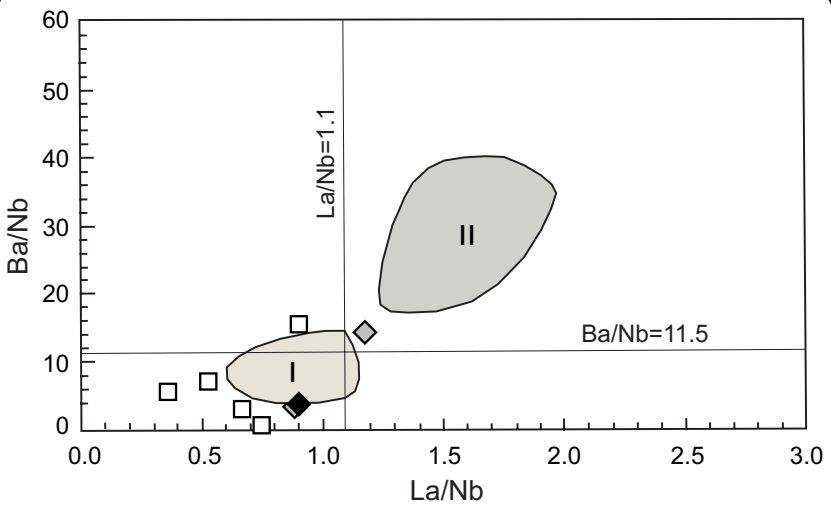

(б)

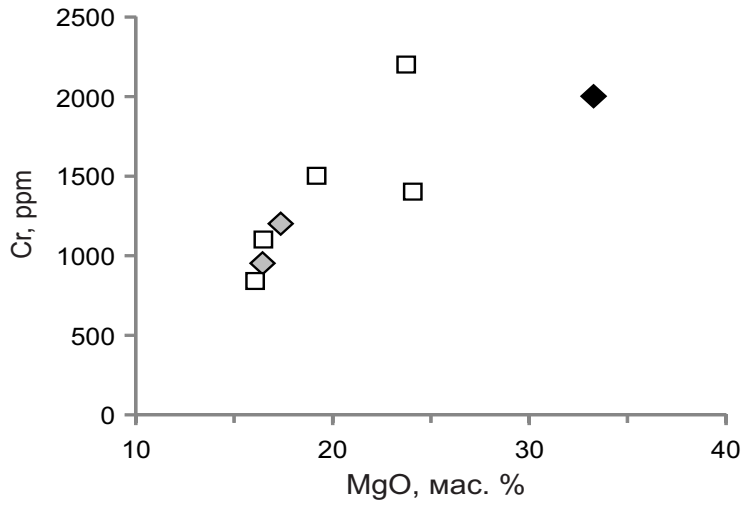

(2)

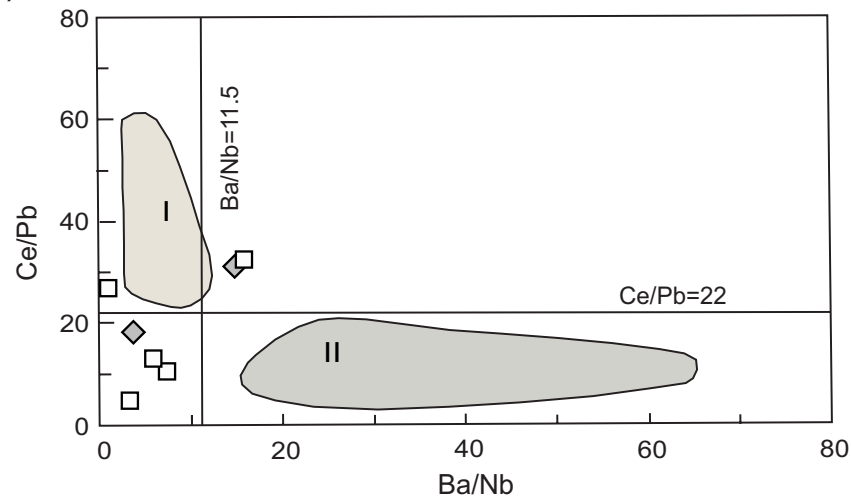

Pис. 8. Соотношения $\mathrm{Ni}-\mathrm{MgO}(a), \mathrm{Cr}-\mathrm{MgO}$ (б), $\mathrm{Ba} / \mathrm{Nb}-\mathrm{La} / \mathrm{Nb}($ ( ) и и $\mathrm{Ce} / \mathrm{Pb}-\mathrm{Ba} / \mathrm{Nb}$ (2) в Бушканайской дайке и жилах Большетагнинского массива.

Поля кимберлитов I и II группы Южной Африки на диаграмме ( $a$ ) по [Becker, Le Roex, 2006]. Условные обозначения см. на рис. 7. На фрагменте (2) не показана точка кимберлита (обр. 51) с $\mathrm{Ce} / \mathrm{Pb}=629$.

Fig. 8. Ratios Ni-MgO (a), Co-MgO (6), $\mathrm{Cr}-\mathrm{MgO}(8)$ and V-MgO (2) in the Bushkanai dike and the veins of the Bol'shaya Tagna massif. Fields of the South African kimberlites in diagram (a) after [Becker, Le Roex, 2006]. See Fig. 7 for the legend. Fragment (2) does not show the kimberlite point of sample $51(\mathrm{Ce} / \mathrm{Pb}$ ratio=629). 
$(a)$

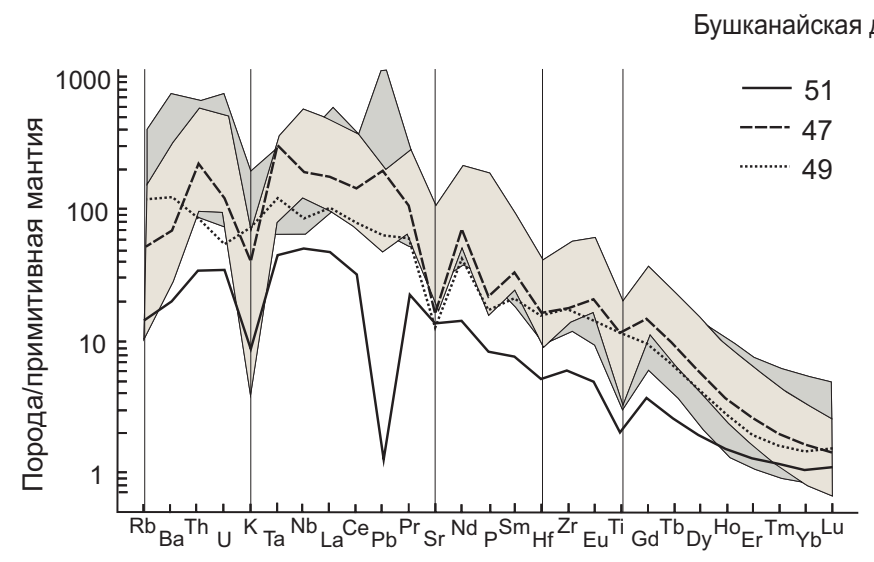

(б)

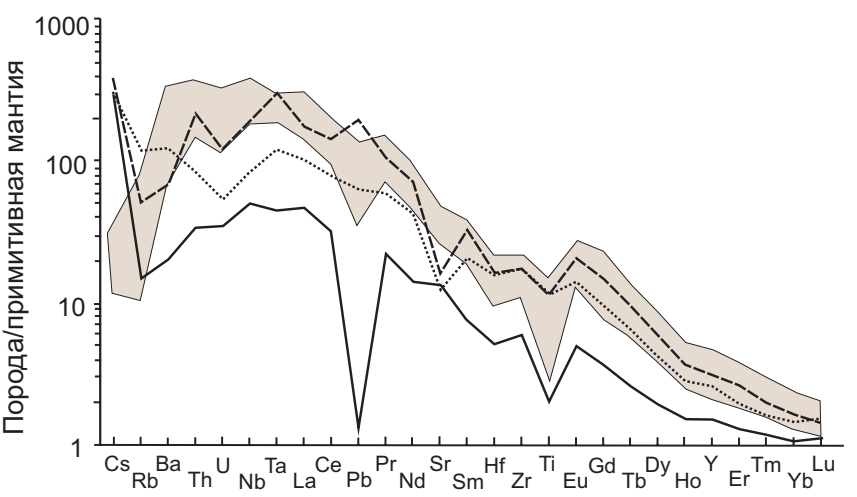

Жилы Большетагнинского массива
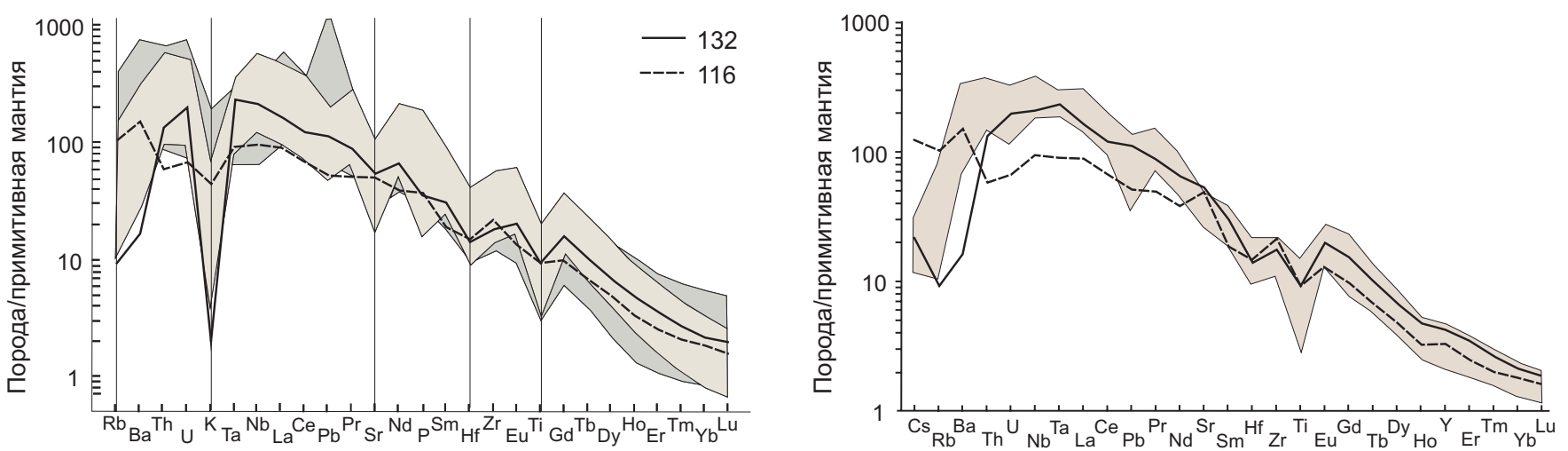

Рис. 9. Мультиэлементные спектры пород Бушканайской дайки и жил Большетагнинского массива в сопоставлении с кимберлитами Южной Африки (a) и Якутской провинции (б).

(a): светло-серое поле - кимберлиты группы I Южной Африки, темно-серое поле - кимберлиты группы II [Becker et al., 2007]; (б): залитое поле - алмазоносные кимберлиты 1-го геохимического типа [Kostrovitsky et al., 2007]. Значения для примитивной мантии по [Sun, McDonough, 1989]. Бушканайская дайка: 51 - кимберлит, 47 и 49 - пикриты (47 - малослюдистый, 49 слюдистый); Большетагнинский массив: 132 и 116 - беспироксеновые пикриты.

Fig. 9. Multi-element spectra of the rocks of the Bushkanai dike and the veins of the Bol'shaya Tagna massif in comparison with the South African (a) and the Yakutian (6) kimberlites.

(a): light gray field - South African kimberlites of group I, dark gray field - group II [Becker et al., 2007]; (б): coloured field - diamondiferous kimberlites of geochemical type 1 [Kostrovitsky et al., 2007]. Values for the primitive mantle after [Sun, McDonough, 1989]. Bushkanai dike: 51 - kimberlite, 47 and 49 - picrites (47 - low mica, 49 - mica). Bol'shaya Tagna massif: 132 and 116 - pyroxene-free picrites.

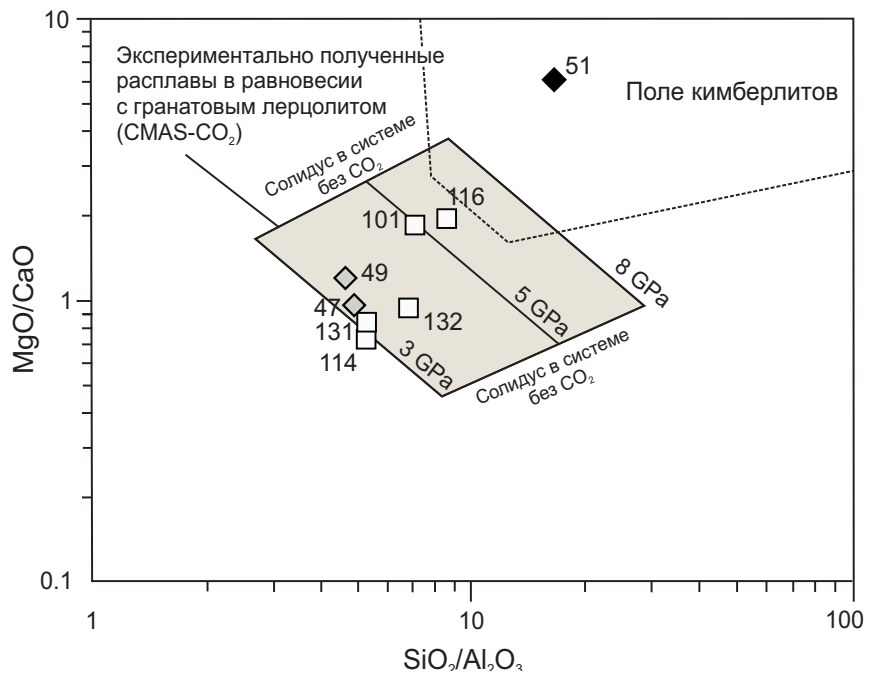

Рис. 10. Диаграмма $\mathrm{MgO} / \mathrm{CaO}-\mathrm{SiO}_{2} / \mathrm{Al}_{2} \mathrm{O}_{3}$ для пород Бушканайской дайки и беспироксеновых пикритов Большетагнинского массива.

Серое поле - экспериментально полученные составы расплава из синтетического карбонатизированного перидотита в диапазоне давлений от 3 до $8 \mathrm{GPa}$ [Gudfinnsson, Presnall, 2005]. Условные обозначения см. на рис. 7.

Fig. 10. Diagram $\mathrm{MgO} / \mathrm{CaO}-\mathrm{SiO}_{2} / \mathrm{Al}_{2} \mathrm{O}_{3}$ for the rocks of the Bushkanai dike and the pyroxene-free picrites of the Bol'shaya Tagna massif.

Gray field - experimentally obtained compositions of melt from synthetic carbonated peridotite (pressure range of 3-8 GPa) [Gudfinnsson, Presnall, 2005]. See Fig. 7 for the legend. 
в основной массе беспироксеновых пикритов бадделеита, кальциртита, богатых $\mathrm{Sr}$ перовскита и апатита, стронцианита, бурбанкита и манганоильменита (последний отмечен и в Бушканайской дайке) [Scott Smith et al., 2018] (см. табл. 1).

Таким образом, по особенностям химического состава породообразующих и акцессорных минералов беспироксеновые пикриты Большетагнинского массива в большей мере соответствуют ультрамафическим лампрофирам - айлликитам, а не кимберлитам [Тарpe et al., 2005]. В то же время и минералогический состав кимберлита Бушканайской дайки также не удовлетворяет в полной мере критериям отнесения к этой группе пород.

Высокие значения Mg\#, содержание $\mathrm{Ni}$ и $\mathrm{Cr}$ в кимберлите Бушканайской дайки показывают, что состав этой породы близок к составу примитивного кимберлитового расплава [Le Roex et al., 2003]. Среди беспироксеновых пикритов Большетагнинского массива только обр. 116 и 101 имеют химический состав, близкий к составу первичных магм кимберлитов (21-30 мас. \% $\mathrm{SiO}_{2}, 22-28$ мас. $\% \mathrm{MgO}, 10-17$ мас. \% CaO, 5-14 мас. \% $\mathrm{CO}_{2}$, 0.2-1.7 мас. \% $\mathrm{K}_{2} 0$ и 660-1190 ppm Ni, согласно [Becker, Le Roex, 2006]), а положительная корреляция между $\mathrm{Ni}$ и $\mathrm{MgO}$ (см. рис. 8, а), Со и MgO предполагает кристаллизацию данной серии пород из ультраосновного расплава, претерпевшего эволюцию в результате фракционирования оливина на пути движения к поверхности. Расплавы, исходные для беспироксеновых пикритов, согласно результатам экспериментов по плавлению карбонатизированного гранатового лерцолита [Gudfinnsson, Presnall, 2005], могли выплавляться при давлении около 5-6 GPa, т.е. на глубине 150-180 км (рис. 10). Основываясь на этих же экспериментальных данных, можно оценить давление, при котором происходило выплавление флогопит-пироксеновых пикритов Бушканайской дайки, величиной около $3 \mathrm{GPa}$. В то же время очень высокие отношения $\mathrm{MgO} / \mathrm{CaO}$ и $\mathrm{SiO}_{2} / \mathrm{Al}_{2} \mathrm{O}_{3}$ в кимберлите Бушканайской дайки указывают на вероятную аккумуляцию оливина в расплаве.

Высокие значения Mg\# (0.73-0.80), содержание $\mathrm{Ni}$ (до 850 ppm) и $\mathrm{Cr}$ (до 2200 ppm) и низкое содержание $\mathrm{Al}_{2} \mathrm{O}_{3}$ в беспироксеновых пикритах Большетагнинского массива позволяют считать, что источником для них, как и для кимберлита Бушканайской дайки, могли быть перидотиты, деплетированные более ранними эпизодами частичного плавления.

Высокие отношения $\mathrm{La} / \mathrm{Yb}, \mathrm{Ce} / \mathrm{Y}, \mathrm{Nb} / \mathrm{Y}$, низкие концентрации HREE и отношение $\mathrm{Zr} / \mathrm{Nb}$ (табл. 2) отражают присутствие граната в источнике и очень низкие степени плавления [Smedley, 1988; Condie, 2003], а обогащенность несовместимыми элементами обусловлена метасоматическим преобразованием деплетированых гранатовых перидотитов карбонатными, карбонатносиликатными расплавами или флюидами [Bogatikov et al., 2001, 2009; Kostrovitsky et al., 2007; Pokhilenko et al., 2015; Le Roex et al., 2003; Becker, Le Roex, 2006; Tappe et al., 2014]. Положение точек состава пород Бушканайской дайки и беспироксеновых пикритов на диаграммax $\mathrm{Nb} / \mathrm{Y}-\mathrm{Zr} / \mathrm{Y}$ и $\mathrm{Zr} / \mathrm{Nb}-\mathrm{Nb} / \mathrm{Th}$ (рис. 11) указывает на (a) $\mathrm{Zr} / \mathrm{Nb}$

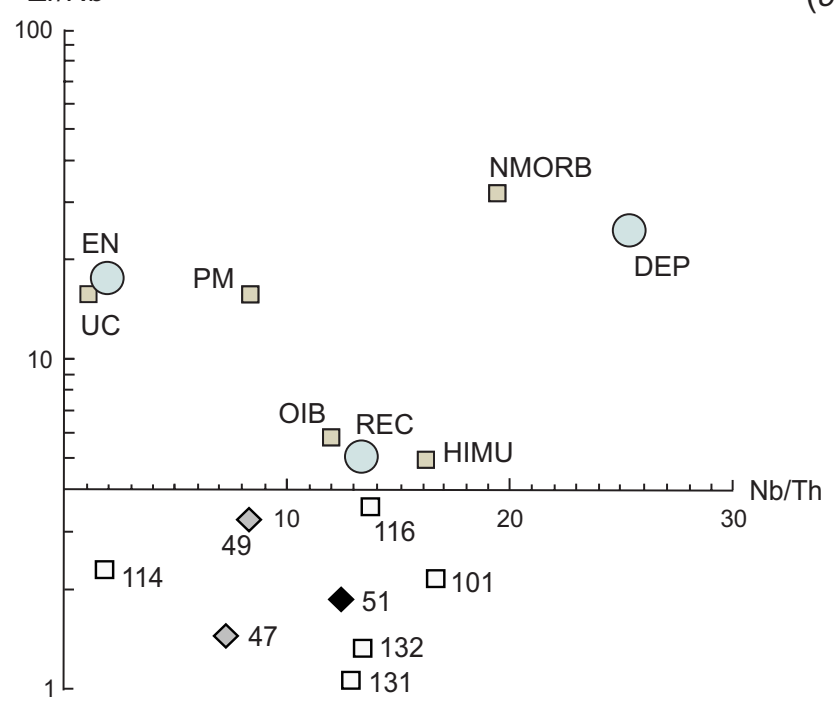

(б)

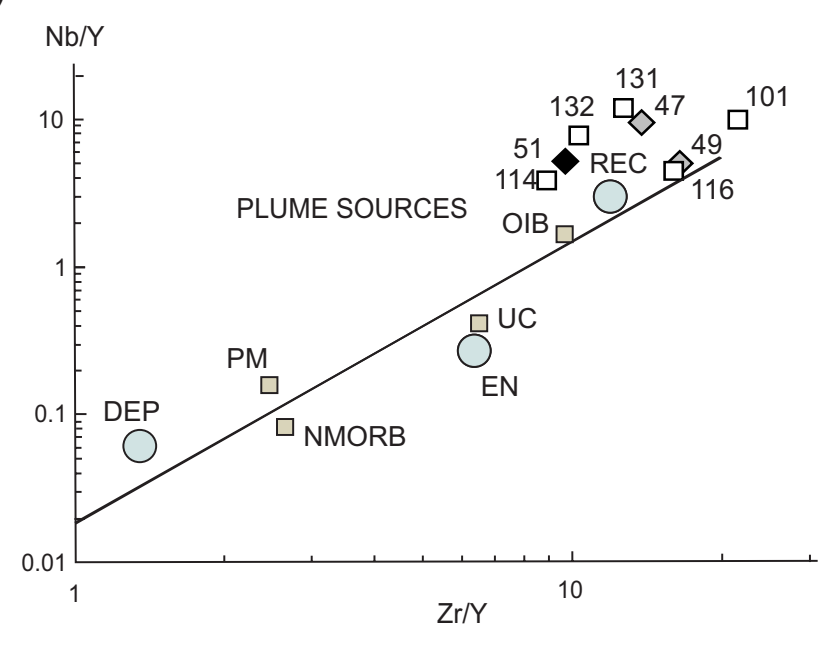

Рис. 11. Распределение кимберлитоподобных пород на диаграммах $\mathrm{Zr} / \mathrm{Nb}-\mathrm{Nb} / \mathrm{Th}(a)$ и Nb/Y-Zr/Y (б).

Гипотетические мантийные источники [Condie, 2003]: EN - обогащенный, DEP - истощенный; REC - рециклированные компоненты. UC - верхняя континентальная кора; PM - примитивная мантия; HIMU - источник с высоким отношением U/Pb; NMORB - обычный базальт океанического хребта; OIB - базальт океанических островов. Другие условные обозначения см. на рис. 7.

Fig. 11. Distribution of kimberlite-like rocks in the $\mathrm{Zr} / \mathrm{Nb}-\mathrm{Nb} / \mathrm{Th}(a)$ and $\mathrm{Nb} / \mathrm{Y}-\mathrm{Zr} / \mathrm{Y}$ (б) diagrams.

Hypothetical mantle sources [Condie, 2003]: EN - enriched, DEP - depleted; REC - recycled components. UC - upper continental crust; PM - primitive mantle; HIMU - source with high U/Pb ratio; NMORB - common ocean ridge basalt; OIB - ocean island basalt. See Fig. 7 for the legend. 
ведущий вклад рециклированного компонента в источники расплавов.

Отношения $\mathrm{Nb} / \mathrm{U}, \mathrm{Nb} / \mathrm{Th}, \mathrm{Th} / \mathrm{Ce}, \mathrm{La} / \mathrm{Nb}, \mathrm{Zr} / \mathrm{Nb}$ варьируются в сравнительно узких диапазонах для кимберлита Бушканайской дайки и беспироксеновых пикритов, за исключением обр. 114 из эндоконтактовой зоны жилы, и близки к таковым в ОІВ (табл. 2).

В то же время беспироксеновые пикриты в целом отличаются от кимберлита Бушканайской дайки повышенными отношениями $\mathrm{Ba} / \mathrm{Th}, \mathrm{Ba} / \mathrm{Nb}, \mathrm{Ba} / \mathrm{La}$ (табл. 2). В совокупности с петрохимическими отличиями, это свидетельствует о формировании кимберлита, флогопит-пироксеновых и беспироксеновых пикритов в локальных магматических очагах со специфическим микроэлементным составом. Аномальные содержания редких элементов в обр. 114 обусловлены изменением химического состава ультраосновного расплава на контакте с карбонатитом.

Взаимоотношения беспироксеновых пикритов с породами Большетагнинского массива показывают, что их внедрение произошло на поздних стадиях становления массива, но до полной его консолидации. Надежные возрастные датировки для щелочных пород и карбонатитов Большетагнинского массива отсутствуют, однако для анкеритовых карбонатитов Белозиминского массива получен возраст $645 \pm 6$ млн лет [Doroshkevich et al., 2016]. Исходя из геологических взаимоотношений, можно полагать, что возраст беспироксеновых пикритов не древнее 650 млн лет (около 640 млн лет). Трубка Южная имеет возраст 645 млн лет [Ashchepkov et al., 2020].

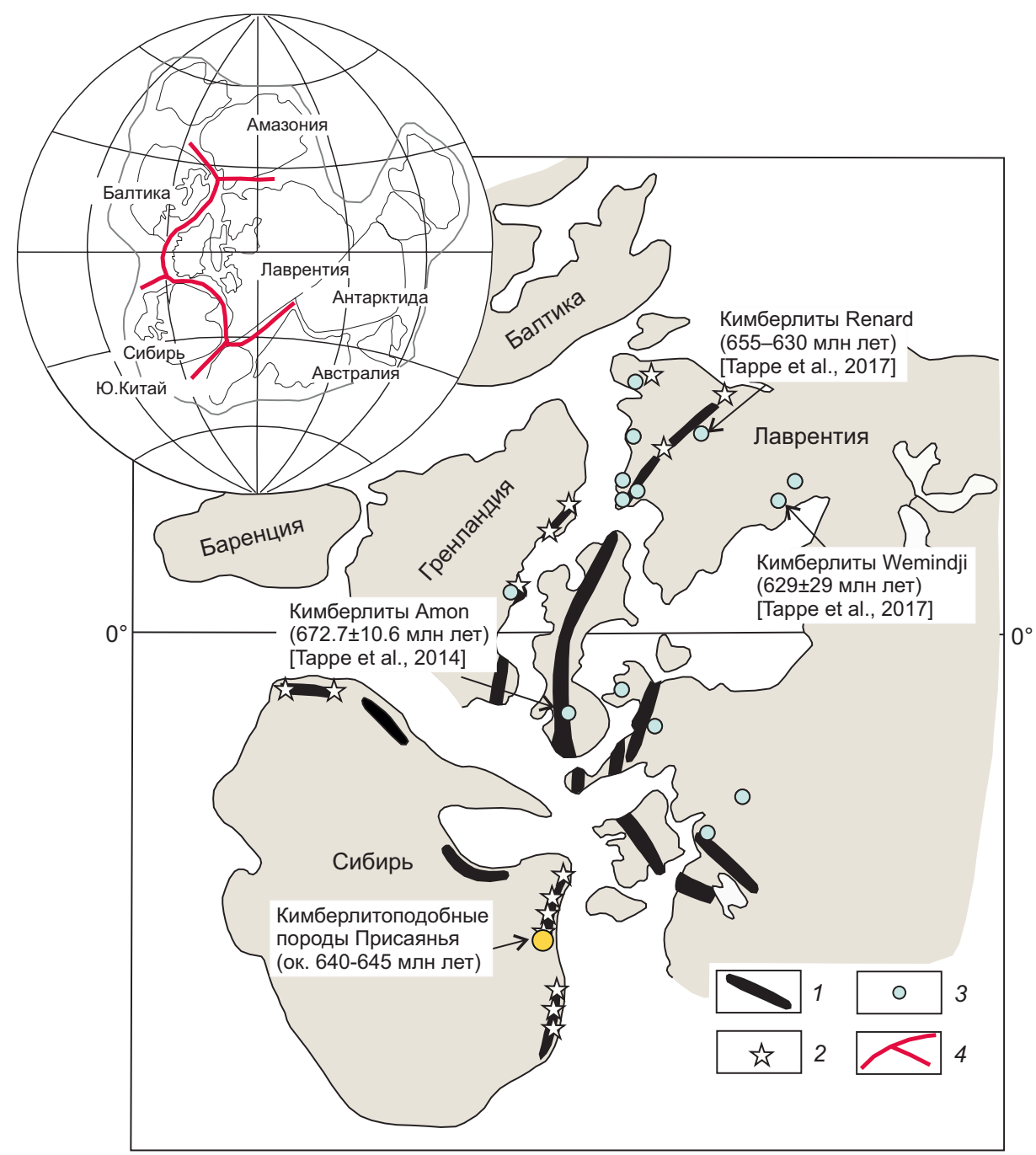

Рис. 12. Схема проявления неопротерозойского ультраосновного щелочного магматизма в связи с распадом Родинии (по [Yarmolyuk, Kovalenko, 2003]).

1 - ультрамафит-мафитовые массивы, грабены и дайковые пояса (712-720 млн лет); 2 - щелочные комплексы с карбонатитами (540-680 млн лет [Khromova et al., 2020]); 3 - кимберлиты, ультрамафические лампрофиры и карбонатиты КанадскоГренландского щита [Tарре et al., 2014, 2017]; 4 - линия раскола суперконтинента Родиния.

Fig. 12. Neoproterozoic ultrabasic-alkaline magmatism in connection with the breakup of Rodinia (after [Yarmolyuk, Kovalenko, 2003]).

1 - ultramafic-mafic massifs, grabens and dike belts (712-720 Ma); 2 - alkaline complexes with carbonatites (540-680 Ma [Khromova et al., 2020]); 3 - kimberlites, ultramafic lamprophyres and carbonatites of the Canada-Greenland shield [Tappe et al., 2014, 2017]; 4 - Rodinia supercontinent break-up line. 
Согласно [Yarmolyuk, Kovalenko, 2003; Kuzmin, Yarmolyuk, 2014], ультраосновные-щелочные с карбонатитами комплексы по периферии Сибирского кратона являются производными мантийного суперплюма, с которым около 700 млн лет назад был связан распад суперконтинента Родиния. Если обратиться к данным по Северо-Канадскому краю плиты Лаврентия, то здесь широко известны проявления неопротерозойских кимберлитов, ультрамафических лампрофиров и карбонатитов с возрастом 680-540 млн лет [Тарpe et al., 2014, 2017] (рис. 12). Очевидно, что в позднем неопротерозое при подъеме мантийного плюма в его головной части происходило частичное плавление верхнемантийного субстрата с образованием ультраосновной щелочной магмы, дифференциация которой в промежуточном очаге привела к образованию массивов ийолитов-мельтейгитов, сиенитов и карбонатитов [Vladykin, 2016]. Одновременно под воздействием тепла суперплюма и в условиях растяжения происходило частичное плавление на разных уровнях метасоматизированной (карбонатизированной) литосферной мантии с образованием небольших порций расплавов, из которых в близповерхностных условиях кристаллизовались кимберлитоподобные породы, флогопит-пироксеновые пикриты и ультрамафические лампрофиры. Формирование обогащенных источников этих пород происходило в результате плюм-литосферного взаимодействия в более раннее время. Согласно [Egorov et al., 2010], модельный возраст $\mathrm{T}_{\mathrm{Nd}}(\mathrm{DM})$ обогащения мантийного источника кимберлита Бушканайской дайки равен 2.1 млрд лет, а флогопит-пироксеновых пикритов этой же дайки - 1.2-1.1 млрд лет.

\section{7. ЗАКЛЮЧЕНИЕ}

Беспироксеновые щелочные пикриты в большей мере соответствуют айлликитам - содержащим первичный карбонат ультрамафическим лампрофирам, а не кимберлитам. Данное утверждение основано на особенностях минерального состава, наличии не характерных для кимберлитов акцессорных минералов, отсутствии высокобарных типоморфных минералов и мантийных ксенолитов и особенностях химического состава минералов (шпинель, ильменит, флогопит, монтичеллит, гранат) [Тарре et al., 2005]. По химическому составу они отвечают железотитанистому низкокалиевому типу кимберлитов и родственных пород, широко представленных на севере Якутской провинции [Kostrovitsky et al., 2007]. Оценки глубины генерации первичного расплава на основе сопоставления с данными экспериментов по плавлению карбонатизированного перидотита [Gudfinnsson, Presnall, 2005] показывают, что выплавление беспироксеновых щелочных пикритов происходило на глубине 150-180 км, а химический состав пород отражает фракционирование оливина на пути движения расплава. Внедрение беспироксеновых пикритов произошло на заключительной стадии становления Большетагнинского щелочно-карбонатитового массива, но до его окончательной консолидации.
По химическому составу только образец из Бушканайской дайки в наибольшей мере отвечает кимберлиту, однако минеральный состав этой породы не удовлетворяет в полной мере критериям отнесения ее к кимберлитам. Особенностью этой породы являются повышенная магнезиальность, низкие концентрации титана, калия и высокозарядных несовместимых элементов при общем сходстве спектра редких элементов со спектрами кимберлитов. Петро- и геохимические различия пород Бушканайской дайки и беспироксеновых щелочных пикритов позволяют предполагать формирование этих пород из разных магматических очагов со специфическим микроэлементным составом.

\section{8. БЛАГОДАРНОСТИ}

Авторы выражают искреннюю признательность д.г.-м.н. С.И. Костровицкому и д.г.-м.н. В.В. Шарыгину за внимательное ознакомление с рукописью и критические замечания, послужившие существенному улучшению качества статьи.

\section{9. ЛИТЕРАТУРА/REFERENCES}

Ashchepkov I., Zhmodik S., Belyanin D., Kiseleva O., Medvedev N., Travin A., Yudin D., Karmanov N., Downes H., 2020. Aillikites and Alkali Ultramafic Lamprophyres of the Beloziminsky Alkaline Ultrabasic-Carbonatite Massif: Possible Origin and Relations with Ore Deposits. Minerals 10 (5), 404. http://dx.doi.org/10.3390/min10050404.

Barnes S.J., Roeder P.L., 2001. The Range of Spinel Compositions in Terrestrial Mafic and Ultramafic Rocks. Journal of Petrology 42 (12), 2279-2302. https://doi.org/10.1093/ petrology/42.12.2279.

Becker M., Le Roex A.P., 2006. Geochemistry of South African on- and off-Craton, Group I and Group II Kimberlites: Petrogenesis and Source Region Evolution. Journal of Petrology 47 (4), 673-703. http://dx.doi.org/10.1093/petrology/ egi089.

Becker M., Le Roex A.P., Class C., 2007. Geochemistry and Petrogenesis of South African Transitional Kimberlites Located on and off the Kaapvaal Craton. South African Journal of Geology 110 (4), 631-646. http://dx.doi.org/10.2113/ gssajg.110.4.631.

Bogatikov O.A., Kononova V.A., Nosova A.A., Kargin A.V., 2009. Polygenetic Sources of Kimberlites, Magma Composition, and Diamond Potential Exemplified by the East European and Siberian Cratons. Petrology 17 (6), 606-625. https://doi.org/10.1134/S0869591109060071.

Bogatikov O.A., Kononova V.A., Pervov V.A., Zhuravlev D.Z., 2001. Sources, Geodynamic Setting of Formation, and Diamond-Bearing Potential of Kimberlites from the Northern Margin of the Russian Plate: A Sr-Nd Isotopic and ICPMS Geochemical Study. Petrology 9 (3), 191-203 (in Russian) [Богатиков O.А., Кононова В.А., Первов В.А., Журавлев Д.З. Источники, геодинамическая обстановка образования и перспективы алмазоносности кимберлитов северной окраины Русской плиты: Sr-Nd изотопия и ICP-MS геохимия // Петрология. 2001. Т. 9. № 3. C. 227-241]. 
Bovkun A.V., 2000. Mineralogy of Oxides from the Binding Material of Yakutian Kimberlites: Genetic and Applied Aspects. Brief PhD Thesis (Candidate of Geology and Mineralogy). Moscow, 22 p. (in Russian) [Бовкун А.В. Минералогия оксидов из связующей массы кимберлитов Якутии (генетические и прикладные аспекты). Автореф. дис ... канд. геол.-мин. наук. М., 2000. 22 с.].

Chalapathi Rao N.V., 2005. A Petrological and Geochemical Reappraisal of the Mesoproterozoic Diamondiferous Majhgawan Pipe of Central India: Evidence for Transitional Kimberlite - Orangeite (Group II Kimberlite) - Lamproite Rock Type. Mineralogy and Petrology 84, 69-106. http:// dx.doi.org/10.1007/s00710-004-0072-2.

Chernyshova E.A., 1991. Geochemistry and Petrology of Dike Rocks of the Lower Sayan Carbonatite Complex. Geochemistry 8, 1096-1110 (in Russian) [Чернышова Е.А. Геохимия и петрология дайковых пород нижнесаянского карбонатитового комплекса // Геохимия. 1991. № 8. С. 1096-1110].

Condie K.C., 2003. Incompatible Element Ratios in Oceanic Basalts and Komatiites: Tracking Deep Mantle Sources and Continental Growth Rates with Time. Geochemistry, Geophysics, Geosystems 4 (1), 1-28. http://dx.doi.org/10.1029/ 2002 GC000333.

Dongre A., Rao N.V., Viljoen K.S., Lehmann B., 2017. Petrology, Genesis and Geodynamic Implication of the Mesoproterozoic - Late Cretaceous Timmasamudram Kimberlite Cluster, Wajrakarur Field, Eastern Dharwar Craton, Southern India. Geoscience Frontiers 8 (3), 541-563. http://dx.doi. org/10.1016/j.gsf.2016.05.007.

Dongre A., Tappe S., 2019. Kimberlite and Carbonatite Dykes within the Premier Diatreme Root (Cullinan Diamond Mine, South Africa): New Insights to Mineralogical-Genetic Classifications and Magma CO 2 Degassing. Lithos 338-339, 155-173. https://doi.org/10.1016/j.lithos.2019.04.020.

Dongre A.N., Viljoen K.S., Chalapathi Rao N.V., Gucsik A., 2016. Origin of Ti-Rich Garnets in the Groundmass of Wajrakarur Field Kimberlites, Southern India: Insights from Epma and Raman Spectroscopy. Mineralogy and Petrology 110, 295-307. http://dx.doi.org/10.1007/s00710-0160428-4.

Doroshkevich A.G., Veksler I.V., Izbrodin I.A., Ripp G.S., Khromova E.A., Posokhov V.F., Travin A.V., Vladykin N.V., 2016. Stable Isotope Composition Ofminerals in the Belaya Zima Plutonic Complex, Russia: Implications for the Sources of the Parental Magma and Metasomatizing Fluids. Journal Asian Earth Science 116, 81-96. http://dx.doi.org/10.1016/ j.jseaes.2015.11.011.

Egorov K.N., Kiselev A.I., Men'Shagin Y.V., Minaeva Y.A., 2010. Lamproite and Kimberlite of the Sayany Area: Composition, Sources, and Diamond Potential. Doklady Earth Sciences 435 (2),1670-1675. https://doi.org/10.1134/S1 $028334 X 10120251$.

Frolov A.A., Belov S.V., 1999. Complex Carbonatite Deposits of the Zima Ore Region (Eastern Sayan, Russia). Geology of Ore Deposits 41 (2), 109-130 (in Russian) [Фролов А.А., Белов С.В. Комплексные карбонатитовые месторождения Зиминского рудного района (Восточный Саян,
Россия) // Геология рудных месторождений. 1999. Т. 41. № 2. С. 109-130].

Frolov A.A., Lapin A.V., Tolstov A.V., Zinchuk N.N., Belov S.V., Burmistrov A.A., 2005. Carbonatites and Kimberlites (Interrelations, Metallogeny, Forecast). NIA-Priroda, Moscow, 540 p. (in Russian) [Фролов А.А., Лапин А.В., Толстов А.В., Зинчук Н.Н., Белов С.В., Бурмистров А.А. Карбонатиты и кимберлиты (взаимоотношения, минералогия, прогноз). М.: НИА-Природа, 2005. 540 с.].

Gladkochub D.P., Mazukabzov A.M., Stanevich A.M., Donskaya T.V., Motova Z.L., Vanin V.A., 2014. Precambrian Sedimentation in the Urik-Iya Graben, Southern Siberian Craton: Main Stages and Tectonic Settings. Geotectonics 48 (5), 359370. https://doi.org/10.1134/S0016852114050033.

Goloburdina M.N., 2017. On the Issue of Terminology and Classification of Kimberlites and Lamproites. Regional Geology and Metallogeny 72, 55-64 (in Russian) [Голобурдина М.Н. К вопросу о номенклатуре и классификации кимберлитов и лампроитов // Региональная геология и металлогения. 2017. № 72. С. 55-64].

Gudfinnsson G.H., Presnall D.C., 2005. Continuous Gradations among Primary Carbonatitic, Kimberlitic, Basaltic, Picritic, and Komatiitic Melts in Equilibrium with Garnet Lherzolite at 3-8 GPa. Journal of Petrology 46 (8), 16451659. http://dx.doi.org/10.1093/petrology/egi029.

Khromova E.A., Doroshkevich A.G., Izbrodin I.A., 2020. Geochemical and $\mathrm{Sr}-\mathrm{Nd}-\mathrm{Pb}$ Isotopic Characteristics of $\mathrm{Al}-$ kaline Rocks and Carbonatites of the Beloziminsky Massif (Eastern Sayan). Geosphere Research 1, 33-55 (in Russian) [Хромова Е.А., Дорошкевич А.Г., Избродин И.А. Геохимическая и $\mathrm{Sr}-\mathrm{Nd}-\mathrm{Pb}$ изотопная характеристики щелочных пород и карбонатитов Белозиминского массива (Восточный Саян) // Геосферные исследования. 2020. № 1. C. 33-55]. http://dx.doi.org/10.17223/25421379/14/3.

Kostrovitsky S.I., Yakovlev D.A., Morikiyo T., Serov I.V., Amirzhanov A.A., 2007. Isotope-Geochemical Systematics of Kimberlites and Related Rocks from the Siberian Platform. Russian Geology and Geophysics 48 (3), 272-290. https://doi.org/10.1016/j.rgg.2007.02.011.

Kuzmin M.I., Yarmolyuk V.V., 2014. Mantle Plumes of Central Asia (Northeast Asia) and Their Role in Forming Endogenous Deposits. Russian Geology and Geophysics 55 (2), 120-143. https://doi.org/10.1016/j.rgg.2014.01.002.

Le Maitre R.W.(Ed.), 2005. Igneous Rocks: A Classification and Glossary of Terms. Cambridge University Press, 256 p.

Le Roex A.P., Bell D.R., Davis P., 2003. Petrogenesis of Group I Kimberlites from Kimberley, South Africa: Evidence from Bulk-Rock Geochemistry. Journal of Petrology 44 (12), 2261-2286. http://dx.doi.org/10.1093/petrology/ egg077.

Minaeva Yu.A., Egorov K.N., 2008. Mineralogical and Petrographic Features of a Kimberlite-Picrite Dike in the Northwestern Part of the Urik-Iya Graben (Eastern Sayan Region). Geology of Ore Deposits 3, 23-39 (in Russian) [Минаева Ю.А., Егоров К.Н. Минералого-петрографические особенности дайки кимберлит-пикритового состава в северозападной части Урикско-Ийского грабена (Восточное Присаянье) // Записки РМО. 2008. № 3. С. 23-39]. 
Mitchell R.H., 1995. Kimberlites, Orangeites and Related Rocks. New York: Plenium Press, 410 p. http://dx.doi.org/ 10.1007/978-1-4615-1993-5.

Odintsov M.M., Tverdokhlebov V.A., Vladimirov B.M., Ilyukhina A.V., Kolesnikova T.P., Konev A.A., 1962. Structure, Volcanism and Diamond Content of the Irkutsk Amphitheater. Publishing House of the USSR Academy of Science, Moscow, 180 p. (in Russian) [Одинцов М.М., Твердохлебов В.А., Владимиров Б.М., Ильюхина А.В., Колесникова Т.П., Конев А.А. Структура, вулканизм и алмазоносность Иркутского амфитеатра. М.: Изд-во АН СССР, 1962. 180 с.].

Petrographic Code of Russia: Magmatic, Metamorphic, Metasomatic and Impact Formations, 2008. VSEGEI Publishing House, Saint Petersburg, 200 p. (in Russian) [Петрографический кодекс России. Магматические, метаморфические, метасоматические, импактные образования. СПб.: Изд-во ВСЕГЕИ, 2008. 200 с.].

Pokhilenko N.P., Afanasiev V.P., Sobolev N.V., Egorov K.N., Smelov A.P., Kostrovitsky S.I., 2012. Stages of Kimberlite Magmatism of the Siberian Platform and Their Productivity: Patterns of Formation and Features of Forecasting Primary Deposits of Diamonds of Various Genetic Types, and New Promising Regions. In: Problems of Minerageny of Russia. Geophysical Center RAS, Moscow, 265-286 (in Russian) [Похиленко Н.П., Афанасьев В.П., Соболев Н.В., Егоров К.Н., Смелов А.П., Костровицкий С.И. Этапы кимберлитового магматизма Сибирской платформы и их продуктивность: закономерности формирования и особенности прогнозирования коренных месторождений алмазов различных генетических типов, новые перспективные регионы // Проблемы минерагении России. М.: ГЦ РАН, 2012. C. 265-286].

Pokhilenko N.P., Agashev A.M., Litasov K.D., Pokhilenko L.N., 2015. Carbonatite Metasomatism of Peridotite Lithospheric Mantle: Implications for Diamond Formation and Carbonatite-Kimberlite Magmatism. Russian Geology and Geophysics 56 (1-2), 280-295. https://doi.org/10.1016/j. rgg.2015.01.020.

Pozharitskaya L.K., Samoilov V.S., 1972. Petrology, Mineralogy and Geochemistry of Carbonatites in Eastern Siberia. Nauka, Moscow, 265 p. (in Russian) [Пожарицкая Л.К., Caмойлов В.С. Петрология, минералогия и геохимия карбонатитов Восточной Сибири. М.: Наука, 1972. 265 с.].

Roeder P.L., Schulze D.J., 2008. Crystallization of Groundmass Spinel in Kimberlite. Journal of Petrology 49 (8), 14731495. http://dx.doi.org/10.1093/petrology/egn034.

Salnikova E.B., Chakhmouradian A.R., Stifeeva M.V., Reguir E.P., Kotov A.B., Gritsenko Y.D., Nikiforov A.V., 2019. Calcic Garnets as a Geochronological and Petrogenetic Tool Applicable to a Wide Variety of Rocks. Lithos 338-339, 141154. https://doi.org/10.1016/j.lithos.2019.03.032.

Scott Smith B.H., Nowicki T.E., Russel J.K., Webb K.J., Mitchell R.H., Hetman C.M., Robey J.V., 2018. A Glossary of Kimberlite and Related Terms. Part 1. Scott-Smith Petrology Inc., North Vancouver, 144 p.

Sekerin A.P., Men'shagin Yu.V., Lashchenov V.A., 1995. The Sayan Province of High-Potassium Alkaline Rocks and Lamproites. Doklady Earth Sciences 342 (1), 82-86 (in Russian)
[Секерин А.П., Меньшагин Ю.В., Лащенов В.А. Присаянская провинция высококалиевых щелочных пород и лампроитов //Доклады РАН. 1995. Т. 342. № 1. С. 82-86].

Smedley P.L., 1988. Trace Element and Isotopic Variations in Scottish and Irish Dinantian Volcanism: Evidence for an OIB- Like Mantle Source. Journal of Petrology 29(2), 413-443. https://doi.org/10.1093/petrology/29.2.413.

Sun S.-S., McDonough W.F., 1989. Chemical and Isotopic Systematics of Oceanic Basalts: Implications for Mantle Composition and Processes. Geological Society of London Special Publications 42 (1), 313-345. https://doi.org/10. 1144/gsl.sp.1989.042.01.19.

Tappe S., Brand N.B., Stracke A., van Acken D., Liu C.-Z., Strauss H., Wu F.-Y., Luguet A., Mitchell R.H., 2017. Plates or Plumes in the Origin of Kimberlites: $\mathrm{U} / \mathrm{Pb}$ Perovskite and Sr-Nd-Hf-Os-C-O Isotope Constraints from the Superior Craton (Canada). Chemical Geology 455, 57-83. http://dx.doi. org/10.1016/j.chemgeo.2016.08.019.

Tappe S., Foley S.F., Jenner G.A., Kjarsgaard B.A., 2005. Integrating Ultramafic Lamprophyres into the IUGS Classification of Igneous Rocks: Rationale and Implications. Journal of Petrology 46 (9), 1893-1900. http://dx.doi.org/10. 1093 /petrology/egi039.

Tappe S., Kjarsgaard B.A., Kurszlaukis S., Nowell G.M., Phillips D., 2014. Petrology and Nd-Hf Isotope Geochemistry of the Neoproterozoic Amon Kimberlite Sills, Baffin Island (Canada): Evidence for Deep Mantle Magmatic Activity Linked to Supercontinent Cycles. Journal of Petrology 55 (10), $2003-$ 2042. http://dx.doi.org/10.1093/petrology/egu048.

Vladykin N.V., 2016. Genesis and Crystallization of Ultramafic Alkaline Carbonatite Magmas of Siberia: Ore Potential, Mantle Sources, and Relationship with Plume Activity. Russian Geology and Geophysics 57 (5), 889-905 (in Russian) [Владыкин Н.В. Модель зарождения и кристаллизации ультраосновных-щелочных-карбонатитовых магм Сибирского региона, проблемы их рудоносности, мантийные источники и связь с плюмовым процессом // Геология и геофизика. 2016. Т. 57. № 5. С. 889-905]. http:// dx.doi.org/10.15372/GiG20160505.

Yarmolyuk V.V., Kovalenko V.I., 2003. Deep Geodynamics and Mantle Plumes: Their Role in the Formation of the Central Asian Fold Belt. Petrology 11 (6) 504-531. [Ярмолюк В.В., Коваленко В.И. Глубинная геодинамика, мантийные плюмы и их роль в формировании Центрально-Азиатского складчатого пояса //Петрология. 2003. Т. 11. № 6. C. 556-586].

Yarmolyuk V.V., Kovalenko V.I., Sal'nikova E.B., Nikiforov A.V., Kotov A.B., Vladykin N.V., 2005. Late Riphean Riftogenesis and Laurasia Break-Up: Data of Geochronological Studies of Ultrabasic Alkaline Complexes in the Southern Framework of the Siberian Craton. Doklady Earth Sciences 404 (3), 400-406 (in Russian) [Ярмолюк В.В., Коваленко В.И., Сальникова Е.Б., Никифоров А.В., Котов А.Б., Владыкин Н.В. Позднерифейский рифтогенез и распад Лавразии: данные геохронологических исследований ультраосновных щелочных комплексов в южном обрамлении Сибирского кратона // Доклады АН. 2005. T. 404. № 3. С. 400-406]. 